Article

\title{
Understanding the Postharvest Phytochemical Composition Fates of Packaged Watercress (Nasturtium officinale R. Br.) Grown in a Floating System and Treated with Bacillus subtilis as PGPR
}

\author{
Giuseppe Pignata ${ }^{1} \mathbb{D}$, Andrea Ertani ${ }^{1, *(\mathbb{D})}$, Manuela Casale ${ }^{1} \mathbb{D}$, Diana Niñirola ${ }^{2,3} \mathbb{D}$, Catalina Egea-Gilabert ${ }^{2,4}(\mathbb{D}$, \\ Juan A. Fernández ${ }^{2,4}$ (D) and Silvana Nicola ${ }^{1}$ (D)
}

1 Department of Agricultural, Forest and Food Sciences, DISAFA University of Turin, UNITO, Via Leonardo da Vinci, 44-Largo Paolo Braccini, 2, 10095 Grugliasco, TO, Italy; giuseppe.pignata@unito.it (G.P.); manuela.casale@unito.it (M.C.); silvana.nicola@unito.it (S.N.)

2 Department of Agronomical Engineering, Universidad Politécnica de Cartagena, Paseo Alfonso XIII, 48, 30203 Cartagena, Spain; dianicax@hotmail.com (D.N.); catalina.egea@upct.es (C.E.-G.); juan.fernandez@upct.es (J.A.F.)

3 Brassica Breeding Group, Sakata Seed Ibérica S.L.U. Plaza Poeta Vicente García, 6, 46021 Valencia, Spain

4 Institute of Plant Biotechnology, Universidad Politécnica de Cartagena, Edificio I+D+i, Campus Muralla del Mar, 30202 Cartagena, Spain

* Correspondence: andrea.ertani@unito.it

check for updates

Citation: Pignata, G.; Ertani, A.; Casale, M.; Niñirola, D.;

Egea-Gilabert, C.; Fernández, J.A.; Nicola, S. Understanding the Postharvest Phytochemical Composition Fates of Packaged Watercress (Nasturtium officinale R.

Br.) Grown in a Floating System and Treated with Bacillus subtilis as PGPR. Plants 2022, 11, 589. https://doi.org/ $10.3390 /$ plants 11050589

Academic Editor: Beatriz Ramos Solano

Received: 21 January 2022

Accepted: 20 February 2022

Published: 22 February 2022

Publisher's Note: MDPI stays neutral with regard to jurisdictional claims in published maps and institutional affiliations.

Copyright: (C) 2022 by the authors. Licensee MDPI, Basel, Switzerland. This article is an open access article distributed under the terms and conditions of the Creative Commons Attribution (CC BY) license (https:// creativecommons.org/licenses/by/ $4.0 /)$.

\begin{abstract}
The physiological changes and phytochemical pathways of processed watercress (Nasturtium officinale $\mathrm{R}$. Br.) undergone during storage are not well known. The objective of this work was to evaluate the respiration rate and the inherent and external quality of watercress inoculated with B. subtilis and packaged as a fresh-cut product and stored at $4{ }^{\circ} \mathrm{C}$ for 11 days. Watercress was grown using continuous flotation (FL) in a greenhouse using substrate disinfection and inoculated or not with Bacillus subtilis as a plant-growth-promoting rhizobacteria (PGPR). The fresh-cut watercress respiration rate and phytochemical profile changed during the shelf life. The inherent phytochemical compounds were retained during the storage of the fresh-cut salad bags. The best results were found in watercress grown in a disinfected substrate but were less satisfactory when seeds and substrates were inoculated with PGPR. In general, the external quality and the pigment contents progressively decreased during the shelf life and the browning enzyme activities responsible for phenolic oxidation increased at different intensities throughout storage. At the end of the shelf-life period, the fresh weight loss of the fresh-cut product was less than $1 \%$ of the original weight. The results demonstrated that watercress grown in FL is a standardised baby leaf vegetable that is suitable for processing in the fresh-cut industry and for storing for more than 10 days. Unclear results were obtained for Bacillus subtilis in the postharvest period due to the inconsistent responses of the different analysed parameters.
\end{abstract}

Keywords: physiological changes; shelf life; postharvest; fresh-cut; baby leaf vegetables; soilless culture systems

\section{Introduction}

Watercress (Nasturtium officinale R. Br.) is a baby leaf vegetable (BLV) that is extensively consumed in Northern Europe, in particular as a fresh-cut product and in salad mixes [1-3]. Watercress is rich in carotenoids, antioxidants, phenols, vitamin C, phosphorus and calcium [4], and it has been used as a medicinal and food crop for over 2000 years [5]. Like any perishable product, fresh-cut leafy vegetables suffer from irreversible quality deterioration because the raw material quality can only be retained and not improved along the supply chain [6]. Chlorophyll $a$ and $b$ contribute to the green intensity and the external appearance 
of plant leaves, but they can degrade during the postharvest shelf life of fresh-cut products $[7,8]$. The yellowing that results from chlorophyll degradation is considered a common disorder for most leafy green vegetables during storage [9]. Similarly, another postharvest decay index is leaf tissue browning due to physiological dynamics, which involves phenolic oxidation and browning enzyme activity $[10,11]$. The antioxidant capacity and vitamin $C$ content of BLVs could reduce the incidence of browning phenomena [12].

Among the phytochemical molecules, carotenoids and phenols are functional compounds that are degraded to different extents and re-biosynthesised in the BLV tissue [13-15]. In order to prolong the fresh-cut product shelf life, it is necessary to have a raw material with a high processing suitability and specific quality characteristics [16-18]. Currently, the fresh-cut vegetable shelf life is ca. 7 days in many European countries because it is affected by raw material quality, handling procedures, processing operations and storage conditions $[6,19]$. BLVs offer some advantages that make them particularly appreciated by the fresh-cut industry. The positive characteristics are related to its: (a) high percentage of edible product, which increases processing efficiency; (b) small whole leaves, which are suitable for mild and fast processing; (c) absence of cutting operations during postharvest, which results in the oxidation phenomena related to phenolic oxidation being reduced to a minimum; (d) attractive presentation and external quality; and (e) excellent phytochemical composition [20-22].

Soilless cultivation systems (SCS) in protected cultivations can be considered a valid alternative to traditional culture systems in soil [23,24]. Among the various SCS, floating growing systems (FGS) can be implemented with a continuous flotation (FL), in which trays continuously float on a water-bed or hydroponic nutrient solution [25]. The nutritional status of BLVs can be rapidly influenced by FL, therefore leading to different results suitable for postharvest storage [26].

Different microbial-based approaches, in the form of biostimulants, are now being proposed for enhancing crop yield [27]. Plant-growth-promoting rhizobacteria (PGPR) represent hopeful and sustainable solutions to increase plant growth and yield [28]. They have been shown to have stimulatory effects on the growth and yield of radish, potato, tomato, beans and ornamental plants [29], as well as to increase the antioxidant capacity in watercress [4]. Moreover, PGPR have the capacity to counteract several stressors in plants [30-32]. In fact, PGPR can increase plant tolerance to stress conditions through chemical and physiological changes that are identified as induced systemic tolerance [31].

There are many PGPR strains, such as Azotobacter, Azospirillum, Bacillus, Rhizobium, Pseudomonas and Serratia, which can be used to improve plant growth [33] through the generation of antioxidants, hormones, and vitamins [34]. Among PGPR, Bacillus species can form long-living spores and metabolites that stimulate plant growth and prevent pathogen infection [35]. The colonization of the roots by bacteria provides a nutrient source, and in exchange, plants are the recipient of bacterial products that stimulate plant growth and provide stress protection to their hosts [35]. In addition, some microbial agents, such as Bacillus subtilis, produce enzymes that degrade the precursors of some hormones related to senescence, helping plants to overcome stress situations [34].

Intense research efforts have been devoted to the development of antagonistic microorganisms to control postharvest diseases [36-38]. So far, biological controls of dry and soft rots with different biocontrol agents such as fungi, bacteria, and yeasts have been reported as effective under experimental conditions [39]. In modern horticulture, substrate disinfection and PGPR inoculation should favour the production of raw materials adapted to the fresh-cut sector, with limited or no use of plant protection products [4]. Little is known about the physiological evolution and phytochemical pathway of processed watercress during storage.

The limited information available on fresh-cut watercress shelf life indicates that watercress leaves are highly perishable and have a 7-day storage [40]. The objective of this research was to study the effect of the inoculation of a watercress growth substrate with Bacillus subtilis through the evaluation of the respiration rate, inherent and external quality, 
and phytochemical composition of watercress packaged as a fresh-cut product and stored at $4{ }^{\circ} \mathrm{C}$ for 11 days.

\section{Materials and Methods}

\subsection{Plant Material}

The raw material was obtained from cultivations carried out in the Experimental Centre of the Department of Agricultural, Forest and Food Sciences (DISAFA) $\left(44^{\circ} 53^{\prime} 11.67^{\prime \prime}\right.$ N; $7^{\circ} 41^{\prime} 7.00^{\prime \prime}$ E-231 $\mathrm{m}$ a.s.1.) in Tetti Frati, Carmagnola (TO), Italy, from June to July in an automatically controlled temperature greenhouse. All plants of watercress (Nasturtium officinale R. Br.) cv. Aqua Large Leaf (Tozer Seeds Co., Cobham, UK) were grown in a lab-scale pilot plant for FGS [41] equipped with 3 benches, each one split into 4 separated flotation beds filled with a nutrient solution. Each bench (replicate) accommodated 4 treatments. Each treatment consisted of 12 trays containing 300 plants each (ca. 1961 plants $\cdot \mathrm{m}^{-2}$ ).

The experiment comprised growing plants in 60-cell Styrofoam trays $(0.51 \times 0.30 \mathrm{~m}$ with cells of $0.044 \mathrm{~m}$ upper and $0.025 \mathrm{~m}$ lower diameters, respectively) containing a specific peat-based horticultural medium (Neuhaus Huminsubstrat N17; Klasmann-Deilmann ${ }^{\circledR}$ $\mathrm{GmbH}$, Geeste, Groß-Hesepe, Germany) floating in a NS. The sown trays were placed in a plastic greenhouse until seed germination. Four days after sowing, the trays were moved into a lab-scale pilot plant equipped with 3 benches, each one split into 4 separated flotation beds $\left(2.50 \times 1.40 \mathrm{~m} ; 0.15 \mathrm{~m}\right.$ depth) and filled with $200 \mathrm{~L}$ of a $40 / 60 \mathrm{~N}-\mathrm{NO}^{3-} / \mathrm{N}^{-\mathrm{NH}^{4+}} \mathrm{NS}^{-1}$ composed of (all in $\mathrm{mM} \cdot \mathrm{L}^{-1}$ ): $12 \mathrm{~N}, 2 \mathrm{P}, 6 \mathrm{~K}, 2 \mathrm{Mg}$, and $2.5 \mathrm{Ca}$. Then, a Lysodin ${ }^{\circledR}$ Multimix formulation of microelements (Intrachem Production S.r.l., Grassobbio, Bergamo, Italy) was added to the NS at a dose of $0.30 \mathrm{~g} \cdot \mathrm{L}^{-1}$.

The harvesting of treated and untreated plants with B. subtilis took place after 24 days of cultivation, and all plants were used for the further sampling. At harvest, the raw material was immediately transferred to the postharvest laboratory to be processed as fresh-cut product.

\subsection{Bacterial Strain and Inoculation}

A total of $50 \%$ of the substrate, which consisted of a specific peat-based horticultural medium (Neuhaus Huminsubstrat N17; Klasmann-Deilmann, GmbH, Geeste, GroßHesepe, Germany) was disinfected (DS) with a steam stream at $100{ }^{\circ} \mathrm{C}$ for $45 \mathrm{~min}$. The remaining part was not disinfected (NDS). The commercial product Larminar ${ }^{\circledR}\left(10^{12} \mathrm{CFU} \cdot \mathrm{g}^{-1}\right.$ of B. subtilis strain AP-01; Agrimor, Agricultura Moderna S.A., Madrid, Spain) was used as a bacterial inoculant (BI). The seeds were sterilised in $20 \% \mathrm{NaOCl}(w / v)$ and washed three times with sterile deionised water. Inoculation was performed twice: the first inoculation was performed one day before sowing, and for the second, 50\% of the disinfected substrate (DS) and $50 \%$ of non-disinfected substrate (NDS) were inoculated with Larminar ${ }^{\circledR}$ at a dose of $0.5 \mathrm{~kg} \cdot \mathrm{m}^{-3}$.

A total of $50 \%$ of the disinfected seeds were inoculated by soaking for $1 \mathrm{~h}$ in a B. subtilis suspension at a concentration of $10^{8} \mathrm{CFU} \cdot \mathrm{mL}^{-1}$ in $0.9 \%$ of a $\mathrm{NaOCl}$ solution $(w / v)$ obtained from Larminar ${ }^{\circledR}$ in Plate Count Agar (PCA) (Fluka Analytical, Sigma-Aldrich S.r.l., Milan, Italy). The non-inoculated (NBI) seeds were kept for $1 \mathrm{~h}$ in $0.9 \% \mathrm{NaOCl}$. Eleven days after sowing, re-inoculation was performed by placing the inoculated trays (substrate and seeds) on a solution containing $0.167 \%$ Larminar $^{\circledR} /$ water $(w / v)$. Shoots of twelve plants per treatment and per block were used for phytochemical analyses. During the postharvest period, six bags per treatment per block were used; we examined one bag per treatment per block at each sampling date throughout the shelf life.

All the analytical determinations were carried out after 1, 3, 5, 7, and 9 days of storage $(\mathrm{d} 1, \mathrm{~d} 3, \mathrm{~d} 5, \mathrm{~d} 7$, and $\mathrm{d} 9$, respectively) and at the end of the shelf life (d11) in the DISAFA analytical laboratories. 


\subsection{Processing, Packaging and Storage Conditions}

The raw material was sorted in a cold temperature room, and any damaged and yellowing shoots were discarded. Then, $125 \mathrm{~g}$ of watercress were packaged in $0.25 \times 0.35 \mathrm{~m}$ thermo-sealed bags that had previously been prepared with polypropylene film with the following characteristics: an oxygen permeance of $1990 \mathrm{~cm}^{3} \mathrm{~m}^{-2} \mathrm{~d}^{-1} \mathrm{bar}^{-1}$, a carbon dioxide permeance of $7800 \mathrm{~cm}^{3} \mathrm{~m}^{-2} \mathrm{~d}^{-1} \mathrm{bar}^{-1}$, a water vapour permeance of $5.8 \mathrm{~g} \mathrm{~m}^{-2} \mathrm{~d}^{-1} \mathrm{bar}^{-1}$. a film thickness of $20 \mu \mathrm{m}$, and a weight of $18.2 \mathrm{~g} \mathrm{~m}^{-2}$ (Alvapack S.r.l., Bologna, Italy). The packaged samples were stored at $4{ }^{\circ} \mathrm{C}$ for an 11-day shelf life in refrigerated chambers (MEDIKA 600; C.F. di Ciro Fiocchetti \& C. S.n.c., Luzzara, (RE), Italy) without light in the display cabinet.

\subsection{Bag Headspace Gas Analysis}

The headspace gas composition in the fresh-cut salad bags $\left(\mathrm{O}_{2} \%\right.$ and $\left.\mathrm{CO}_{2} \%\right)$ was measured using a Check Point Handheld Gas Analyzer (PBI-Dansensor AS, Ringsted, Denmark). To avoid modifications in the headspace gas composition due to gas sampling, each bag was used only once [8].

\subsection{Fresh-Cut Product Fresh Weight Loss}

Fresh-cut product fresh weight loss (FWL) was measured by weighing the bags daily during storage and progressively calculated based on the value from $\mathrm{d} 0$ as a decay index of freshness.

\subsection{Pigment Content Analysis}

Frozen tissue $(1.0 \mathrm{~g})$ from each sample was homogenised with $20.0 \mathrm{~mL}$ of an $80 \%$ acetone/water $(v / v)$ solution and extracted at $4{ }^{\circ} \mathrm{C}$ for $12 \mathrm{~h}$ in the dark. The extract was filtered and used for the spectrophotometric determination of chlorophyll $a$, chlorophyll $b$, and carotenoid (Chl. $a$, Chl. $b$ and Car., respectively) contents at wavelengths of 662, 645, and $470 \mathrm{~nm}$, respectively [42]. The results were expressed according to the Lichtenthaler and Wellburn (1983) formulas.

\subsection{Antioxidant Capacity}

Frozen tissue $(2.0 \mathrm{~g})$ from each sample was mixed with $20.0 \mathrm{~mL}$ of pure methanol, incubated for $60 \mathrm{~min}$, homogenised, and subsequently centrifuged at $958 \times g$ at $4{ }^{\circ} \mathrm{C}$ for $15 \mathrm{~min}$. The antioxidant capacity $(\mathrm{AC})$ was determined using the ferric-reducing ability of the plasma (FRAP) assay [43], by mixing $30 \mu \mathrm{L}$ of the sample methanol extract with $900 \mu \mathrm{L}$ of the FRAP reagent [14]. The mixture was incubated at $20{ }^{\circ} \mathrm{C}$ for $4 \mathrm{~min}$, and the absorbance was spectrophotometrically determined at a wavelength of $593 \mathrm{~nm}$.

\subsection{Total Phenolic Content}

The total phenolic (TP) content was determined by mixing $100 \mu \mathrm{L}$ of the sample methanol extract, prepared as described in Section 2.6, and the antioxidant capacity by using the Folin-Ciocalteau reagent [44]. After incubating the mixture for $3 \mathrm{~min}, 400 \mu \mathrm{L}$ of a $7.5 \%$ sodium carbonate/water $(w / v)$ solution were added. The new solution was mixed, incubated at $20^{\circ} \mathrm{C}$ for $30 \mathrm{~min}$ in the dark, and then used for spectrophotometric determination at a wavelength of $760 \mathrm{~nm}$ [42].

\subsection{Browning Potential and Soluble o-Quinone Content}

Frozen tissue $(5.0 \mathrm{~g})$ from each sample was homogenised with $10.0 \mathrm{~mL}$ of methanol and subsequently filtered with gauze and centrifuged at $15,040 \times g$ at $4{ }^{\circ} \mathrm{C}$ for $15 \mathrm{~min}$ [45]. The absorbance was spectrophotometrically determined at a wavelength of $340 \mathrm{~nm}$ to establish the browning potential (BP) and a wavelength of $437 \mathrm{~nm}$ to establish the soluble o-quinone (So-Q) content [46]. 


\subsection{Enzyme Activity Analysis}

Frozen tissue $(0.5 \mathrm{~g})$ from each sample was ground in a mortar with liquid $\mathrm{N}$, mixed with $4.0 \mathrm{~mL}$ of a $50 \mathrm{mM}$ sodium phosphate buffer (PBS, pH 7.0), and centrifuged at $19,934 \times g$ at $4{ }^{\circ} \mathrm{C}$ for $20 \mathrm{~min}$ for peroxidase (POD) and polyphenol oxidase (PPO) activity analysis. POD activity was measured using $100 \mu \mathrm{L}$ of the sample mixed with $2.9 \mathrm{~mL}$ of a reaction mixture prepared with $\mathrm{PBS} \mathrm{pH} 7.0,0.05 \%$ guaiacol, and $10 \mathrm{mM} \mathrm{H}_{2} \mathrm{O}_{2}$ [42]. The mixture was used for the spectrophotometric determination of absorbance at a wavelength of $470 \mathrm{~nm}$ at time $0\left(\mathrm{t}_{0}\right)$ and after $1 \mathrm{~min}\left(\mathrm{t}_{1}\right)$. The results were expressed according to the difference between $t_{1}$ and $t_{0}$. In order to establish the PPO activity, $100 \mu \mathrm{L}$ of the sample extract were mixed with $1.9 \mathrm{~mL}$ of the reaction mix prepared with PBS pH 7.0 and $2.5 \mathrm{mM}$ pyrocatechol [47]. The mixture was subsequently incubated at $25^{\circ} \mathrm{C}$ for $30 \mathrm{~min}$ and used for spectrophotometric determination at a wavelength of $480 \mathrm{~nm}$ [42].

To conduct the phenylalanine ammonia lyase (PAL) activity analysis, frozen tissue $(0.5 \mathrm{~g})$ taken from each sample was ground in a mortar with liquid $\mathrm{N}$ and subsequently mixed thoroughly with $4.0 \mathrm{~mL}$ of a $50 \mathrm{mM}$ sodium phosphate buffer (PBS, pH 8.0) and $0.01 \mathrm{~g}$ of polyvinylpyrrolidone. The mixture was then centrifuged at $19,934 \times \mathrm{g}$ at $4{ }^{\circ} \mathrm{C}$ for $20 \mathrm{~min}[47,48]$, and $100 \mu \mathrm{L}$ of the sample extract were mixed with $1.4 \mathrm{~mL}$ of PBS pH 8.0 and $0.5 \mathrm{~mL}$ of a $50 \mathrm{mM} \mathrm{L}$-phenylalanine solution. The mixture was incubated at $40^{\circ} \mathrm{C}$ for $60 \mathrm{~min}$ and used for spectrophotometric determination at a wavelength of $290 \mathrm{~nm}$ [42]. All the spectrophotometric analyses were conducted using a Beckman DU ${ }^{\circledR}-65$ spectrophotometer (Beckman Coulter Inc., Fullerton, CA, USA).

\subsection{Ascorbic Acid and Dehydroascorbic Acid Contents}

Frozen tissue $(10.0 \mathrm{~g})$ from each sample was ground in a mortar with liquid $\mathrm{N}$ and mixed with $10.0 \mathrm{~mL}$ of an extraction solution prepared with $1 \mathrm{~L}$ of a $5 \%$ methanol/ultrapure water $(v / v)$ solution, $0.168 \mathrm{~g} \mathrm{~L}^{-1}$ of sodium fluoride, $21.014 \mathrm{~g} \mathrm{~L}^{-1}$ of citric acid, and $0.50 \mathrm{~g} \mathrm{~L}^{-1}$ of ethylenediaminetetraacetic acid. The mixture was centrifuged at $3823 \times g$ at $4{ }^{\circ} \mathrm{C}$ for $5 \mathrm{~min}$, and the supernatant was filtered. High-performance liquid chromatography (HPLC) analyses were performed using HPLC Series 1200 (Agilent Technologies, Waldbronn, Baden-Württemberg, Germany; column C18 Zorbax Eclipse XDB-C18 $4.6 \times 150$ mm, $5 \mu \mathrm{m}$, Agilent Technologies, Santa Clara, CA, USA) after dehydroascorbic acid (DHAA) derivatisation. The derivatisations were performed by mixing $750 \mu \mathrm{L}$ of sample extract with $250 \mu \mathrm{L}$ of the o-phenylendiamine (OPDA) aqueous solution and incubating the mixture at $20^{\circ} \mathrm{C}$ for $37 \mathrm{~min}$ in the dark. The ascorbic acid (AA) and DHAA contents were determined at wavelengths of 261 and $348 \mathrm{~nm}$, respectively [3,14].

\subsection{Tissue Ion and Salt Contents}

Frozen tissue $(10.0 \mathrm{~g})$ from each sample was stomached with $10.0 \mathrm{~mL}$ of distilled water and then filtered and used for nitrate, phosphate, and calcium carbonate $\left(\mathrm{NO}_{3}{ }^{-}\right.$, $\mathrm{PO}_{4}{ }^{3-}$, and $\mathrm{CaCO}_{3}$, respectively) content determination using a refractometric kit (Merck Reflectoquant RQflex2 ${ }^{\odot}$; Merck KGaA, Darmstadt, Hessen, Germany), following the manufacturer's instructions.

\subsection{Sampling Size, Statistical Analysis and Experimental Design}

The statistical experimental design was a randomised complete block design (RCBD). A two-factorial experimental design (2 substrate disinfections $\times 2$ B. subtilis inoculations $\times 3$ blocks) was adopted. Two factors were considered: (a) the use of disinfected and non-disinfected substrates (DS and NDS, respectively) and (b) the use of inoculated and non-inoculated seeds and substrates (BI and NBI, respectively) obtained by applying Bacillus subtilis as PGPR [4].

Six bags per treatment per block were used during the postharvest period; we examined one bag per treatment per block at each sampling date throughout the shelf life. The data were subjected to analysis of variance (ANOVA) using the Statistical Package 
for Social Science (SPSS Version 19.0; SPSS Inc., Chicago, IL, USA). The interactions were represented by the standard error.

\section{Results and Discussion}

Beneficial microorganisms could be considered a preharvest biotic factor that affects fruit and vegetable quality and enhances shelf lives [49,50]. In this study, the phytochemical content of fresh-cut watercress, grown with or without Bacillus subtilis, during the shelf-life period was evaluated. The results showed that the $\mathrm{O}_{2}$ content in the headspace of all the fresh-cut salad bags was consumed, $\mathrm{CO}_{2}$ was produced [23,51-53], and the respiration rate was intense in the first five days of the shelf life (Table 1).

Table 1. Bag headspace gas composition $\left(\mathrm{O}_{2}\right.$ and $\left.\mathrm{CO}_{2}\right)$ in the fresh-cut watercress during its shelf life (NDS: non-disinfected substrate; DS: disinfected substrate; NBI: non-inoculated seeds and substrates; BI: seeds and substrates inoculated with B. subtilis).

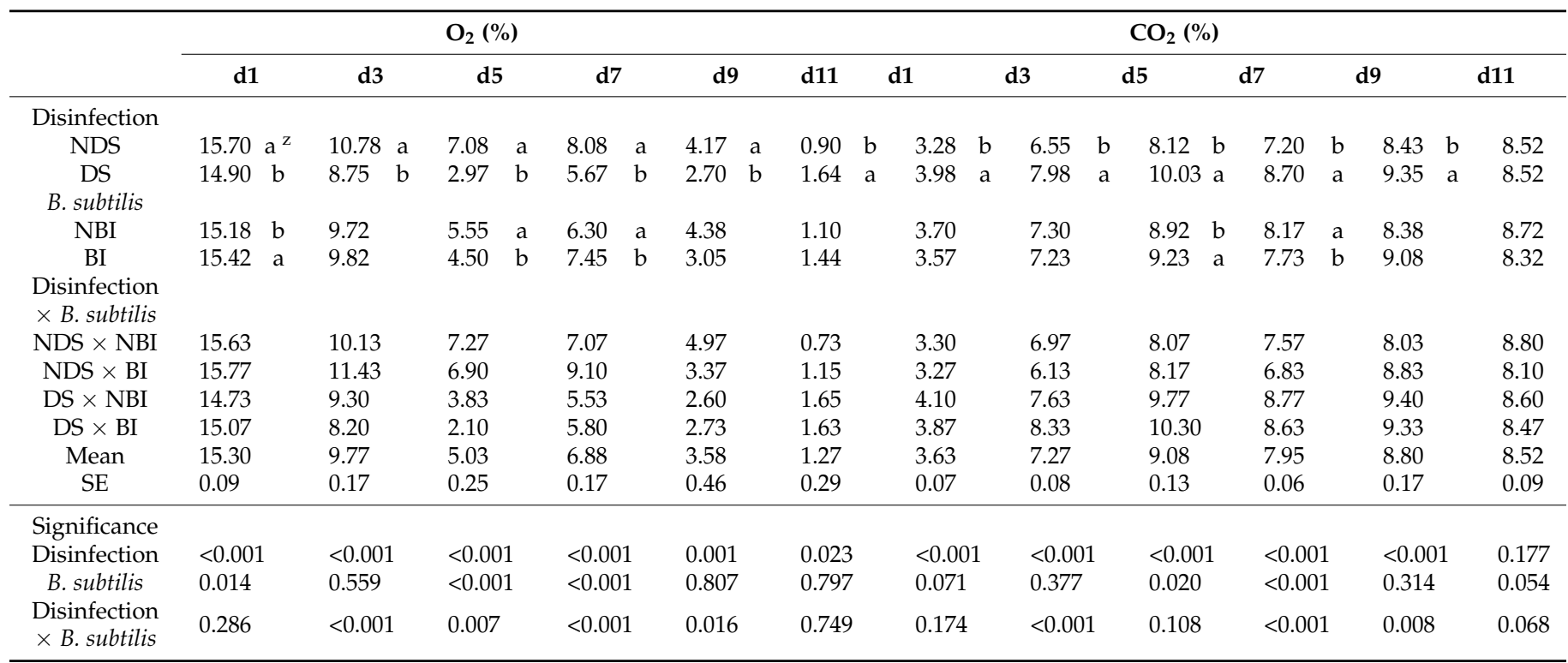

${ }^{\mathrm{z}}$ Values in the same column following the same letter are not statistically different at $p<0.05$ according to F-test. Disinfection $\times$ B. subtilis values are the means of the replicates. SE: standard error.

In particular, the B. subtilis inoculation increased the $\mathrm{O}_{2}$ content at $\mathrm{d} 1$ and $\mathrm{d} 7$ (Table 1). $\mathrm{BI}$ had a higher $\mathrm{O}_{2}$ content at $\mathrm{d} 1$ and $\mathrm{CO}_{2}$ at $\mathrm{d} 5$ than $\mathrm{NBI}(+2 \%$ and $+4 \%$, respectively). DS had a higher $\mathrm{CO}_{2}$ concentration at $\mathrm{d} 5$ and $\mathrm{O}_{2}$ content at $\mathrm{d} 11$ than $\mathrm{NDS}(+24 \%$ and $+82 \%$, respectively). The average $\mathrm{CO}_{2}$ content of the bag headspace at $\mathrm{d} 11$ was ca. $8.5 \%$. Additionally, the substrate disinfection augmented these two parameters over time, except for the $\mathrm{CO}_{2}$ concentration at d11. NDS had a higher $\mathrm{O}_{2}$ content and lower $\mathrm{CO}_{2}$ concentration than DS ( $+5 \%$ and $-18 \%$, respectively) at $\mathrm{d} 1$. The disinfection $\times$ B. subtilis interaction decreased the $\mathrm{O}_{2}$ and $\mathrm{CO}_{2}$ amount in the headspace of the fresh-cut salad bags from $\mathrm{d} 3 \mathrm{do} \mathrm{d} 9$, with the exception of $\mathrm{d} 5$ for the $\mathrm{CO}_{2}$ content (Table 1 ).

DS $\times$ BI had the lowest $\mathrm{O}_{2}$ content at $\mathrm{d} 3$ and $\mathrm{d} 5$ and the highest $\mathrm{CO}_{2}$ content at $\mathrm{d} 3$. NDS $\times$ BI showed the highest $\mathrm{O}_{2}$ content and the lowest $\mathrm{CO}_{2}$ content in bag headspace at $\mathrm{d} 3$ and $\mathrm{d} 7$. NDS $\times$ NBI had the highest $\mathrm{O}_{2}$ content at $\mathrm{d} 5$ and $\mathrm{d} 9$ and the lowest $\mathrm{CO}_{2}$ content at d9. DS $\times$ NBI had the lowest $\mathrm{O}_{2}$ amount and the highest $\mathrm{CO}_{2}$ content at both $\mathrm{d} 7$ and $\mathrm{d} 9$. The $\mathrm{CO}_{2}$ concentration at levels above $10 \%$ in bags during refrigerated storage was due to the high permeance of the film used and the reduced cutting surface of plants, which slowed the respiration rate and extended the shelf life [22]. The high $\mathrm{O}_{2}$ and low $\mathrm{CO}_{2}$ values were also reported in a paper from 2014 [40] in which the authors studied the effects of growing cycle and nutrient solution aeration on the yield, quality, and on shelf life of watercress grown in a floating system. 
During storage, the FWL was not affected by the treatments (data not shown) and was less than $1 \%$ of the original weight at the end of the shelf life. The upper threshold limit value to consider fresh leafy green vegetables marketable is $2 \%$ [26]. These results are in line with other studies on BLVs such as garden cress (Lepidium sativum L.) [42,54].

The disinfection $\times$ B. subtilis interaction determined a higher accumulation of chlorophylls at $\mathrm{d} 3$ and $\mathrm{d} 7$ (Table 2). Specifically, DS $\times$ BI had the highest chlorophyll content at $\mathrm{d} 3$ and $\mathrm{d} 7$; the lowest chlorophyll contents at $\mathrm{d} 3$ and $\mathrm{d} 7$ were found in NDS $\times$ BI and DS $\times$ NBI, respectively. At $\mathrm{d} 9, \mathrm{DS} \times \mathrm{NBI}$ had the highest Car. content and NDS $\times$ BI had the lowest Car. content (Table 3).

Table 2. Chlorophyll $a$ (Chl. $a$ ) and chlorophyll $b$ (Chl. $b$ ) contents in the fresh-cut watercress during its shelf life (NDS: non-disinfected substrate; DS: disinfected substrate; NBI: non-inoculated seeds and substrates; BI: seeds and substrates inoculated with B. subtilis). The results are expressed per fresh weight (FW).

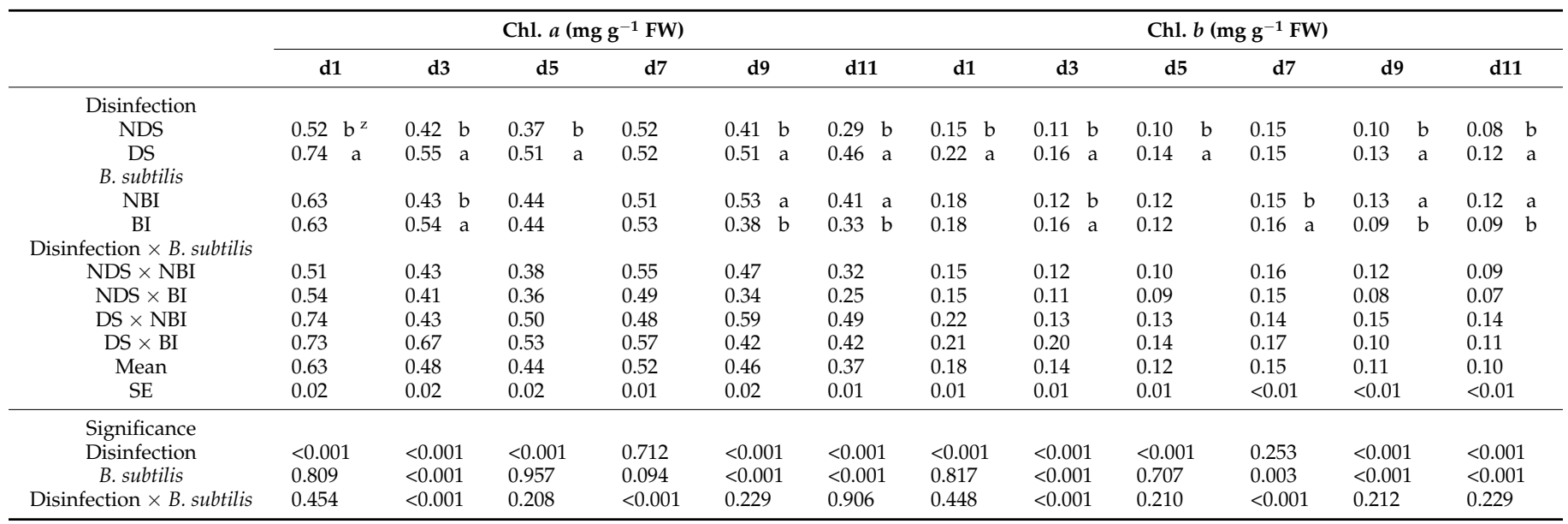

${ }^{\mathrm{z}}$ Values in the same column following the same letter are not statistically different at $p<0.05$ according to F-test. Disinfection $\times$ B. subtilis values are the means of the replicates. SE: standard error.

Table 3. Carotenoid (Car.) content in the fresh-cut watercress during its shelf life (NDS: nondisinfected substrate; DS: disinfected).

\begin{tabular}{|c|c|c|c|c|c|c|c|c|c|c|c|}
\hline & \multicolumn{11}{|c|}{ Car. $\left(\mathrm{mg} \mathrm{g}^{-1} \mathrm{FW}\right)$} \\
\hline & \multicolumn{2}{|c|}{ d1 } & \multicolumn{2}{|c|}{ d3 } & \multicolumn{2}{|c|}{ d5 } & \multirow[t]{2}{*}{ d7 } & \multicolumn{2}{|c|}{ d9 } & \multicolumn{2}{|c|}{ d11 } \\
\hline & & & & & & & & & & & \\
\hline NDS & 0.19 & $b^{z}$ & 0.08 & $\mathrm{~b}$ & 0.15 & $\mathrm{~b}$ & 0.20 & 0.17 & $\mathrm{~b}$ & 0.14 & $\mathrm{~b}$ \\
\hline DS & 0.27 & a & 0.13 & a & 0.21 & a & 0.20 & 0.21 & a & 0.19 & a \\
\hline B. subtilis & & & & & & & & & & & \\
\hline NBI & 0.23 & & 0.08 & $\mathrm{~b}$ & 0.18 & & 0.19 & 0.22 & a & 0.18 & a \\
\hline BI & 0.23 & & 0.12 & a & 0.18 & & 0.20 & 0.16 & $\mathrm{~b}$ & 0.15 & $\mathrm{~b}$ \\
\hline \multicolumn{12}{|l|}{ Disinfection $\times$ B. subtilis } \\
\hline NDS $\times$ NBI & 0.19 & & 0.08 & & 0.16 & & 0.21 & 0.19 & & 0.15 & \\
\hline $\mathrm{NDS} \times \mathrm{BI}$ & 0.20 & & 0.07 & & 0.15 & & 0.19 & 0.14 & & 0.12 & \\
\hline $\mathrm{DS} \times \mathrm{NBI}$ & 0.27 & & 0.08 & & 0.20 & & 0.18 & 0.24 & & 0.21 & \\
\hline $\mathrm{DS} \times \mathrm{BI}$ & 0.26 & & 0.17 & & 0.21 & & 0.21 & 0.17 & & 0.18 & \\
\hline Mean & 0.23 & & 0.10 & & 0.18 & & 0.20 & 0.19 & & 0.17 & \\
\hline SE & 0.01 & & 0.01 & & 0.01 & & $<0.01$ & 0.01 & & 0.01 & \\
\hline \multicolumn{12}{|l|}{ Significance } \\
\hline Disinfection & $<0.001$ & & $<0.001$ & & $<0.001$ & & 0.300 & $<0.001$ & & $<0.001$ & \\
\hline B. subtilis & 0.965 & & $<0.001$ & & 0.913 & & 0.091 & $<0.001$ & & $<0.001$ & \\
\hline Disinfection $\times$ B. subtilis & 0.305 & & $<0.001$ & & 0.169 & & $<0.001$ & 0.009 & & 0.491 & \\
\hline
\end{tabular}

${ }^{\mathrm{z}}$ Values in the same column following the same letter are not statistically different at $p<0.05$ according to F-test Disinfection $\times B$. subtilis values are the means of the replicates. SE: standard error. 
These results were confirmed by other studies in which treatment with biostimulant products influenced the functioning of enzymes in the photosynthetic process, causing the stimulation of Ribulose-1,5- bisphosphate carboxylase/oxygenase [55-57].

Decreases in chlorophyll content during shelf life have already been described in many species, e.g., for baby leaf lettuce (Lactuca sativa L.) [58] and cultivated rocket (Eruca sativa Mill.) grown in FGS [59]. The chlorophyll degradative evolution during the shelf life has shown a different trend: the Chl. a content reduction was faster than that of Chl. $b$ for frozen watercress during storage $[42,60]$. The higher amount of Chl. $a$ than Chl. $b$ measured over time could be caused by the transformation of Chl. $b$ into Chl. $a$ prior to its degradation $[8,9]$.

All photosynthetic organisms accumulate carotenoids that play essential roles in photosystem assembly, photoprotection, and light harvesting. Usually, plant tissues accumulate lutein, $b$-carotene, violaxanthin and neoxanthin: the changes in the composition of these compounds alter photosynthesis and photoprotection [61]. In our study, the Car. content detected in the fresh-cut watercress remained constant during the entire shelf-life period. Similar data have been reported for $\beta$-carotene in spinach (Spinacia oleracea L.), lamb's lettuce (Valerianella locusta L.), and mizuna (Brassica rapa L.). On the contrary, small to moderate decreases have been observed in watercress during shelf life [62]

Studies on antioxidant activity of vegetables have been commonly limited to phenols and flavonoids, as well as to the influence of single phenolics on antioxidant activity, but they have often forgotten the importance of antioxidant activity. Additionally, most studies have been conducted on plants cultivated under conventional farming [63]. Therefore, results from cultivation in soilless systems can be valuable. Here, NBI had a higher antioxidant capacity at $\mathrm{d} 1$ than $\mathrm{BI}(+8 \%)$, while $\mathrm{BI}$ had a higher $\mathrm{AC}$ than NBI at $\mathrm{d} 3$ and $\mathrm{d} 9(+6 \%$ and $+12 \%$, respectively). In general, AC was steady throughout the entire freshcut watercress shelf life, as already observed in fresh-cut garden cress stored in a light condition at $4{ }^{\circ} \mathrm{C}$ for $5 \mathrm{~d}$ [42] and fresh-cut baby leaf spinach stored at $5{ }^{\circ} \mathrm{C}$ for $10 \mathrm{~d}$ [23]. In our study, DS had a higher AC than NDS (ca. $+19 \%$ ) at d1, d3, d9, and d11. Both the main factors affected the AC over time with the exception of the B. subtilis inoculation at $\mathrm{d} 11$ (Table 4). The disinfection $\times$ B. subtilis interaction increased the AC at $\mathrm{d} 5$ and $\mathrm{d} 7$ (Table 4). DS $\times \mathrm{BI}$ at $\mathrm{d} 5$ and DS $\times$ NBI at $\mathrm{d} 7$ showed the highest $\mathrm{AC}$. The lowest AC was found in both samplings in NDS $\times$ NBI. Similar results were obtained in a recent study in which the addition of compost extracts to a nutrient solution improved the content of potentially healthy substances compounds such as total phenols and flavonoids, as well as antioxidant capacity, and reduced the senescence of plant tissues trough the production of 1-aminocyclopropane-1-carboxylase [64].

BI showed a higher So-Q content than NBI at both $\mathrm{d} 7$ and $\mathrm{d} 11(+26 \%$ and $+11 \%$, respectively) (Table 5). At d5, treatments had no significant effect on the So-Q content, the average value of which was $0.48 \mathrm{Abs}_{437}$. The So-Q content increased in an approximatively constant fashion from $\mathrm{d} 1$ to $\mathrm{d} 11$, except at $\mathrm{d} 5$ when a peak was registered. The So-Q content measured in the leafy tissue is the result of the combination of the browning enzyme activities, the AA content (which is responsible for the PPO catalytic activity inhibitions), and the TP oxidation to quinones [65]. NDS $\times$ BI had the lowest BP at $\mathrm{d} 5$ and the highest So-Q content at $\mathrm{d} 3$. DS had a higher BP and So-Q contents at $\mathrm{d} 7$ than NDS $(+23 \%$ and $+27 \%$, respectively). The BP decrease in fresh-cut watercress observed in the present experiment could have been due to the storage temperature used for the shelf-life simulation, which slows phenolic compound oxidation $[66,67]$. 
Table 4. Antioxidant capacity (AC) and total phenolic (TP) content in the fresh-cut watercress during its shelf life (NDS: non-disinfected substrate; DS: disinfected substrate; NBI: non-inoculated seeds and substrates; BI: seeds and substrates inoculated with B. subtilis). The results are expressed per fresh weight $(\mathrm{FW})$.

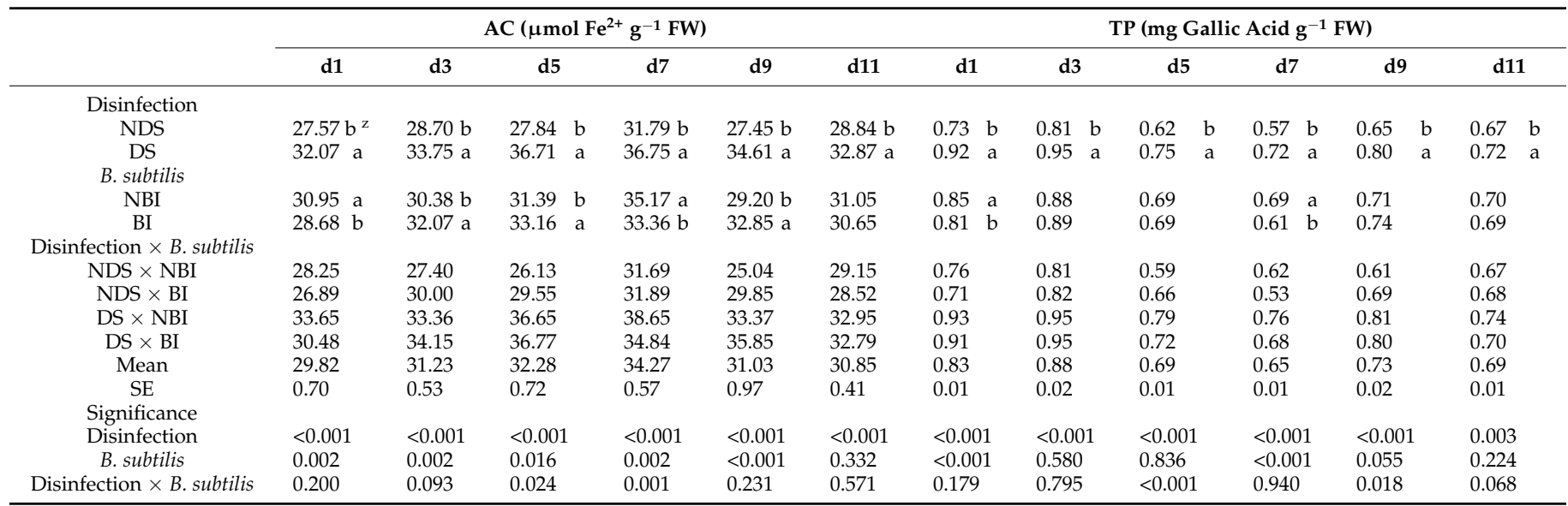

${ }^{\mathrm{z}}$ Values in the same column following the same letter are not statistically different at $p<0.05$ according to F-test. Disinfection $\times$ B. subtilis values are the means of the replicates. SE: standard error.

Table 5. Browning potential (BP) and soluble o-quinone (So-Q) content in the fresh-cut watercress during its shelf life (NDS: non-disinfected substrate; DS: disinfected substrate; NBI: non-inoculated seeds and substrates; BI: seeds and substrates inoculated with B. subtilis).

\begin{tabular}{|c|c|c|c|c|c|c|c|c|c|c|c|c|c|c|c|}
\hline & \multicolumn{7}{|c|}{$\mathrm{BP}\left(\mathrm{Abs}_{340}\right)$} & \multicolumn{8}{|c|}{ So-Q $\left(\mathbf{A b s}_{437}\right)$} \\
\hline & d1 & d3 & \multicolumn{2}{|l|}{ d5 } & d7 & d9 & d11 & d1 & d3 & \multirow[t]{2}{*}{ d5 } & d7 & \multicolumn{2}{|l|}{ d9 } & \multicolumn{2}{|l|}{ d11 } \\
\hline Disinfection & & & & & & & & & & & & & & & \\
\hline NDS & $1.09 \mathrm{~b}^{\mathrm{z}}$ & $0.99 \mathrm{~b}$ & 1.10 & $\mathrm{~b}$ & $0.90 \mathrm{~b}$ & 0.95 & $0.98 \mathrm{~b}$ & $0.24 \mathrm{~b}$ & 0.33 & 0.47 & $0.20 \mathrm{~b}$ & 0.20 & $\mathrm{~b}$ & 0.37 & \\
\hline DS & $1.17 \mathrm{a}$ & $1.12 \mathrm{a}$ & 1.15 & a & $1.11 \mathrm{a}$ & 0.97 & $1.07 \mathrm{a}$ & 0.29 a & 0.30 & 0.49 & $0.26 \mathrm{a}$ & 0.24 & a & 0.38 & \\
\hline B. subtilis & & & & & & & & & & & & & & & \\
\hline NBI & $1.19 \mathrm{a}$ & 1.07 & 1.11 & & 0.99 & $1.02 \mathrm{a}$ & 1.03 & 0.27 & $0.29 \mathrm{~b}$ & 0.49 & $0.21 \mathrm{~b}$ & 0.22 & & 0.36 & b \\
\hline BI & $1.07 \mathrm{~b}$ & 1.04 & 1.14 & & 1.02 & $0.90 \mathrm{~b}$ & 1.02 & 0.26 & $0.34 \quad \mathrm{a}$ & 0.47 & 0.26 a & 0.22 & & 0.40 & a \\
\hline \multicolumn{16}{|l|}{ Disinfection $\times$ B. subtilis } \\
\hline NDS $\times$ NBI & 1.09 & 0.96 & 1.12 & & 0.90 & 0.97 & 0.94 & 0.22 & 0.29 & 0.48 & 0.17 & 0.20 & & 0.35 & \\
\hline $\mathrm{NDS} \times \mathrm{BI}$ & 1.10 & 1.01 & 1.08 & & 0.91 & 0.93 & 1.02 & 0.26 & 0.37 & 0.45 & 0.24 & 0.21 & & 0.39 & \\
\hline $\mathrm{DS} \times \mathrm{NBI}$ & 1.30 & 1.18 & 1.10 & & 1.08 & 1.07 & 1.12 & 0.31 & 0.30 & 0.49 & 0.24 & 0.24 & & 0.36 & \\
\hline $\mathrm{DS} \times \mathrm{BI}$ & 1.05 & 1.07 & 1.20 & & 1.14 & 0.88 & 1.02 & 0.26 & 0.31 & 0.48 & 0.28 & 0.24 & & 0.41 & \\
\hline Mean & 1.13 & 1.06 & 1.12 & & 1.01 & 0.96 & 1.02 & 0.26 & 0.32 & 0.48 & 0.23 & 0.22 & & 0.38 & \\
\hline SE & 0.04 & 0.02 & 0.02 & & 0.03 & 0.02 & 0.03 & 0.01 & 0.02 & 0.01 & 0.01 & $<0.01$ & & 0.01 & \\
\hline \multicolumn{16}{|l|}{ Significance } \\
\hline Disinfection & 0.023 & $<0.001$ & 0.041 & & $<0.001$ & 0.235 & 0.003 & $<0.001$ & 0.091 & 0.093 & $<0.001$ & $<0.001$ & & 0.269 & \\
\hline B. subtilis & 0.001 & 0.138 & 0.261 & & 0.291 & $<0.001$ & 0.632 & 0.814 & 0.010 & 0.098 & $<0.001$ & 0.390 & & 0.004 & \\
\hline Disinfection $\times$ B. subtilis & $<0.001$ & $<0.001$ & 0.006 & & 0.401 & $<0.001$ & 0.003 & $<0.001$ & 0.038 & 0.316 & 0.116 & 0.022 & & 0.656 & \\
\hline
\end{tabular}

${ }^{\mathrm{z}}$ Values in the same column following the same letter are not statistically different at $p<0.05$ according to F-test Disinfection $\times$ B. subtilis values are the means of the replicates. SE: standard error.

One reaction to stress is the production of reactive oxygen species (ROS) that trigger oxidative stress [68]. Plants control ROS by enzymatic antioxidants, including peroxidase [69]. In our experiment, the substrate disinfection decreased POD enzyme activities over time, except for at $\mathrm{d} 3$ (Table 6). The $B$. subtilis inoculation decreased the POD activity at both $\mathrm{d} 1$ and $\mathrm{d} 5$ and increased the PPO activity at $\mathrm{d} 7$. PAL activity diminished at $\mathrm{d} 1, \mathrm{~d} 3$, and $\mathrm{d} 9$ (Tables 6 and 7). The disinfection $\times$ B. subtilis interaction significantly influenced the POD, PPO and PAL activities over time, with the exception of the POD activity at $\mathrm{d} 3$ and the PAL activity at both $\mathrm{d} 3$ and $\mathrm{d} 9$ (Tables 6 and 7). At $\mathrm{d} 1$, NDS $\times$ NBI had the highest POD activity and NDS $\times$ BI had the lowest activity. DS $\times$ NBI had the highest POD activity at both $\mathrm{d} 5$ and d7; DS $\times$ BI had the lowest POD activity from d5 to d11. During the shelf life of the last two samplings, the highest POD activity was found in NDS $\times$ BI. NDS had a higher POD activity than DS at $\mathrm{d} 3(+13 \%)$. NDS $\times$ BI had the highest PPO activity at $\mathrm{d} 1, \mathrm{~d} 5$ and d11. DS $\times$ BI had the lowest PPO activity at $\mathrm{d} 1, \mathrm{~d} 9$ and $\mathrm{d} 11$ and the highest PPO activity at d7. DS $\times$ NBI showed the highest PPO activity at $d 3$, and NDS $\times$ NBI showed the lowest 
values from $\mathrm{d} 3$ to $\mathrm{d} 7$. NDS $\times \mathrm{NBI}$ also had the highest PPO activity at $\mathrm{d} 9$. DS $\times$ NBI had the highest PAL activity at both $\mathrm{d} 1$ and $\mathrm{d} 11$.

Table 6. Peroxidase (POD) and polyphenol oxidase (PPO) activities in the fresh-cut watercress during its shelf life (NDS: non-disinfected substrate; DS: disinfected substrate; NBI: non-inoculated seeds and substrates; BI: seeds and substrates inoculated with B. subtilis). The results are expressed per fresh weight (FW).

\begin{tabular}{|c|c|c|c|c|c|c|c|c|c|c|c|c|c|}
\hline & \multicolumn{7}{|c|}{ POD (Unit g ${ }^{-1}$ FW) } & \multicolumn{6}{|c|}{ PPO (Unit g ${ }^{-1}$ FW) } \\
\hline & d1 & d3 & \multicolumn{2}{|l|}{ d5 } & \multirow[t]{2}{*}{ d7 } & d9 & d11 & \multirow[t]{2}{*}{ d1 } & \multirow[t]{2}{*}{ d3 } & \multirow[t]{2}{*}{ d5 } & \multirow[t]{2}{*}{ d7 } & \multirow[t]{2}{*}{ d9 } & \multirow[t]{2}{*}{ d11 } \\
\hline Disinfection & & & & & & & & & & & & & \\
\hline NDS & $2.36 \mathrm{~b}^{\mathrm{z}}$ & 3.16 a & 3.53 & a & 3.24 & $4.25 \mathrm{a}$ & 5.18 a & 11.87 & $14.26 \mathrm{~b}$ & 19.61 & $19.10 \mathrm{~b}$ & 32.14 a & 31.64 \\
\hline DS & $2.55 \quad \mathrm{a}$ & $2.80 \mathrm{~b}$ & 3.13 & $\mathrm{~b}$ & 3.19 & $3.31 \mathrm{~b}$ & $4.31 \mathrm{~b}$ & 11.33 & $14.63 \mathrm{a}$ & 19.46 & $21.13 \mathrm{a}$ & $30.33 \mathrm{~b}$ & 31.13 \\
\hline B. subtilis & & & & & & & & & & & & & \\
\hline NBI & 2.58 & 2.94 & 3.83 & a & 3.28 & 3.51 & 4.52 & 11.80 & 14.32 & 19.32 & $18.96 \mathrm{~b}$ & 33.09 a & 31.20 \\
\hline BI & $2.34 \quad \mathrm{~b}$ & 3.03 & 2.84 & $\mathrm{~b}$ & 3.16 & 4.05 & 4.98 & 11.39 & 14.57 & 19.75 & $21.28 \mathrm{a}$ & $29.39 \mathrm{~b}$ & 31.57 \\
\hline \multicolumn{14}{|l|}{ Disinfection $\times$ B. subtilis } \\
\hline NDS $\times$ NBI & 2.61 & 3.14 & 3.71 & & 3.16 & 3.13 & 4.38 & 11.12 & 13.83 & 19.10 & 18.38 & 33.45 & 30.26 \\
\hline $\mathrm{NDS} \times \mathrm{BI}$ & 2.12 & 3.18 & 3.35 & & 3.32 & 5.36 & 5.99 & 12.61 & 14.69 & 20.12 & 19.83 & 30.84 & 33.01 \\
\hline $\mathrm{DS} \times \mathrm{NBI}$ & 2.55 & 2.74 & 3.95 & & 3.40 & 3.88 & 4.65 & 12.47 & 14.81 & 19.54 & 19.54 & 32.72 & 32.14 \\
\hline $\mathrm{DS} \times \mathrm{BI}$ & 2.56 & 2.87 & 2.32 & & 2.99 & 2.73 & 3.97 & 10.18 & 14.44 & 19.39 & 22.72 & 27.94 & 30.12 \\
\hline Mean & 2.46 & 2.98 & 3.33 & & 3.22 & 3.78 & 4.75 & 11.60 & 14.44 & 19.54 & 20.12 & 31.24 & 31.38 \\
\hline $\mathrm{SE}$ & 0.05 & 0.07 & 0.14 & & 0.08 & 0.42 & 0.25 & 0.45 & 0.18 & 0.29 & 0.39 & 0.43 & 0.61 \\
\hline \multicolumn{14}{|l|}{ Significance } \\
\hline Disinfection & $<0.001$ & $<0.001$ & 0.006 & & 0.509 & 0.029 & 0.001 & 0.234 & 0.039 & 0.614 & $<0.001$ & $<0.001$ & 0.411 \\
\hline B. subtilis & $<0.001$ & 0.228 & $<0.001$ & & 0.118 & 0.208 & 0.063 & 0.371 & 0.165 & 0.133 & $<0.001$ & $<0.001$ & 0.556 \\
\hline Disinfection $\times$ B. subtilis & $<0.001$ & 0.584 & $<0.001$ & & $<0.001$ & $<0.001$ & $<0.001$ & $<0.001$ & 0.001 & 0.046 & 0.027 & 0.014 & $<0.001$ \\
\hline
\end{tabular}

${ }^{\mathrm{z}}$ Values in the same column following the same letter are not statistically different at $p<0.05$ according to F-test. Disinfection $\times$ B. subtilis values are the means of the replicates. SE: standard error.

Table 7. Phenylalanine ammonia lyase (PAL) activity in the fresh-cut watercress during its shelf life (NDS: non-disinfected substrate; DS: disinfected substrate; NBI: non-inoculated seeds and substrates; BI: seeds and substrates inoculated with B. subtilis). The results are expressed per fresh weight (FW).

\begin{tabular}{|c|c|c|c|c|c|c|c|c|c|c|}
\hline & \multicolumn{10}{|c|}{ PAL ( $\mu$ mol cinnamic acid $\left.h^{-1} g^{-1} \mathrm{FW}\right)$} \\
\hline & \multicolumn{2}{|c|}{ d1 } & \multicolumn{2}{|c|}{ d3 } & d5 & \multicolumn{2}{|c|}{ d7 } & \multicolumn{2}{|c|}{ d9 } & d11 \\
\hline & & & & & & & & & & \\
\hline NDS & 0.102 & $b^{z}$ & 0.119 & $\mathrm{~b}$ & 0.129 & 0.103 & $\mathrm{~b}$ & 0.151 & $\mathrm{~b}$ & 0.154 \\
\hline DS & 0.115 & a & 0.148 & a & 0.132 & 0.118 & a & 0.171 & a & 0.149 \\
\hline \multicolumn{11}{|l|}{ B. subtilis } \\
\hline NBI & 0.113 & a & 0.140 & a & 0.127 & 0.105 & $\mathrm{~b}$ & 0.169 & $\mathrm{a}$ & 0.155 \\
\hline BI & 0.103 & $\mathrm{~b}$ & 0.126 & $\mathrm{~b}$ & 0.134 & 0.116 & $\mathrm{a}$ & 0.154 & $\mathrm{~b}$ & 0.148 \\
\hline \multicolumn{11}{|l|}{ Disinfection $\times$ B. subtilis } \\
\hline NDS $\times$ NBI & 0.088 & & 0.125 & & 0.138 & 0.109 & & 0.156 & & 0.150 \\
\hline NDS × BI & 0.116 & & 0.113 & & 0.120 & 0.097 & & 0.146 & & 0.158 \\
\hline $\mathrm{DS} \times \mathrm{NBI}$ & 0.138 & & 0.155 & & 0.116 & 0.102 & & 0.182 & & 0.159 \\
\hline $\mathrm{DS} \times \mathrm{BI}$ & 0.091 & & 0.140 & & 0.148 & 0.135 & & 0.161 & & 0.138 \\
\hline Mean & 0.108 & & 0.133 & & 0.130 & 0.110 & & 0.161 & & 0.151 \\
\hline SE & 0.004 & & 0.003 & & 0.004 & 0.003 & & 0.003 & & 0.006 \\
\hline \multicolumn{11}{|l|}{ Significance } \\
\hline Disinfection & 0.005 & & $<0.001$ & & 0.465 & $<0.001$ & & $<0.001$ & & 0.451 \\
\hline B. subtilis & 0.023 & & $<0.001$ & & 0.133 & $<0.001$ & & $<0.001$ & & 0.302 \\
\hline Disinfection $\times$ B. subtilis & $<0.001$ & & 0.656 & & $<0.001$ & $<0.001$ & & 0.115 & & 0.026 \\
\hline
\end{tabular}

${ }^{\mathrm{z}}$ Values in the same column following the same letter are not statistically different at $p<0.05$ according to F-test. Disinfection $\times B$. subtilis values are the means of the replicates. SE: standard error.

The lowest PAL activity was found in NDS $\times$ NBI at $\mathrm{d} 1$, while the lowest value was found in DS $\times$ BI at d11. The highest PAL activity was found at $\mathrm{d} 5$ and $\mathrm{d} 7$ in DS $\times$ BI. The lowest PAL activity was observed in DS $\times \mathrm{NBI}$ at $\mathrm{d} 5$ and in NDS $\times \mathrm{BI}$ at $\mathrm{d} 7$. At both $\mathrm{d} 3$ and d9, DS had a higher PAL activity than NDS $(+24 \%$ and $+13 \%$, respectively) and NBI had a higher PAL activity than BI $(+11 \%$ and $+10 \%$, respectively). The POD, PPO and PAL activity increased during the shelf-life period. Specifically, the trend was linear for the POD and PPO and variable for PAL throughout the postharvest period. Improvements in the enzyme activities during shelf life have already been reported for fresh-cut garden cress stored in a light condition at $4{ }^{\circ} \mathrm{C}$ for $5 \mathrm{~d}$ [42], for fresh-cut cultivated rocket stored at $4{ }^{\circ} \mathrm{C}$ for $10 \mathrm{~d}$ [59], 
and for fresh-cut fully mature head Romaine lettuce subject to high-intensity light (HIL, 2500 lx), low-intensity light (LIL, 500 lx), darkness, and storage at $4{ }^{\circ} \mathrm{C}$ for $7 \mathrm{~d}$ [65].

Increased PAL activity and related enzymes that function in secondary metabolism has been found in a few species $[69,70]$ after the supply of biostimulants, such as PGPR [71].

Vegetables are rich in various phytochemicals, and biologically active substances with beneficial health effects such as ascorbic acid [72]. Here, the substrate disinfection significantly influenced the AA content at both $\mathrm{d} 3$ and $\mathrm{d} 5$; both the main factors affected the DHAA content over time, apart from at $\mathrm{d} 9$ of the shelf life (Table 8). The disinfection $\times$ B. subtilis interaction decreased the ascorbic acid content at $\mathrm{d} 1, \mathrm{~d} 5$ and $\mathrm{d} 9$ and the DHAA content at $\mathrm{d} 9$ (Table 8). NDS $\times$ NBI had the highest AA content at d1 and the highest DHAA content at $d 9$. At the same samplings, the lowest AA and DHAA contents were found in DS $\times$ NBI. The highest and lowest AA contents were found in NDS $\times$ BI and DS $\times \mathrm{BI}$, respectively, at $\mathrm{d} 5$.

Table 8. Ascorbic acid (AA) and dehydroascorbic acid (DHAA) contents in the fresh-cut watercress during its shelf life (NDS: non-disinfected substrate; DS: disinfected substrate; NBI: non-inoculated seeds and substrates; BI: seeds and substrates inoculated with B. subtilis). The results are expressed per fresh weight $(\mathrm{FW})$.

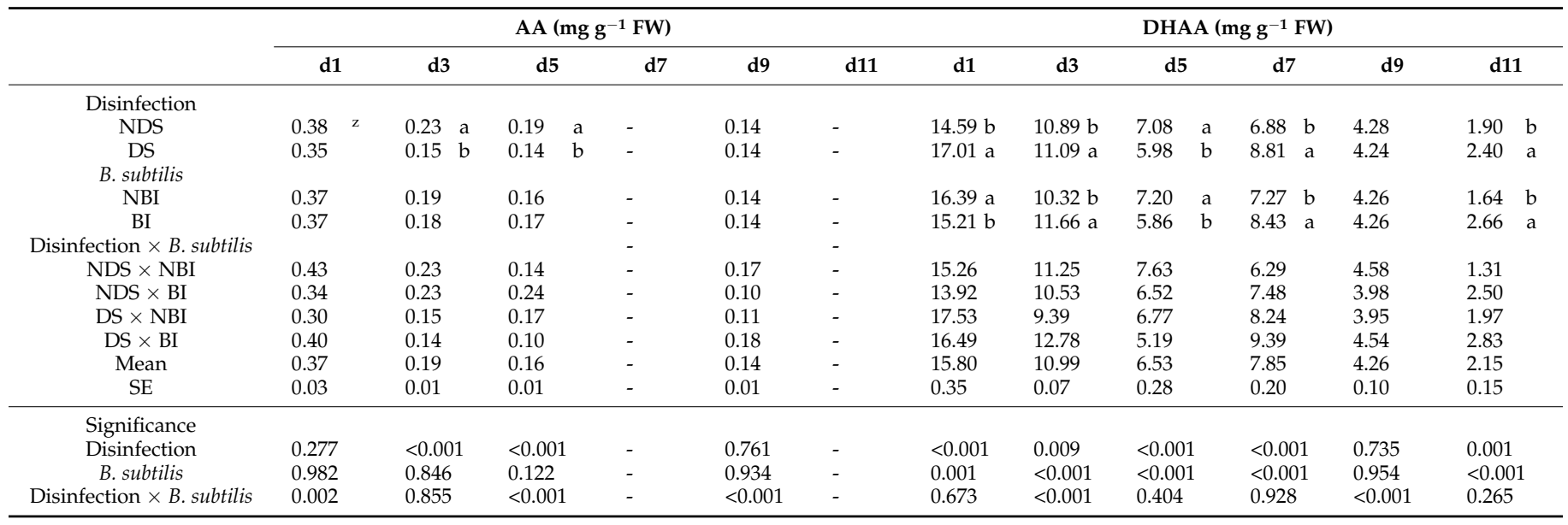

${ }^{\mathrm{z}}$ Values in the same column following the same letter are not statistically different at $p<0.05$ according to F-test Disinfection $\times$ B. subtilis values are the means of the replicates. SE: standard error.

Opposite results were found at $\mathrm{d} 9$. At $\mathrm{d} 3, \mathrm{DS} \times \mathrm{BI}$ and $\mathrm{DS} \times \mathrm{NBI}$ had the highest and lowest DHAA contents, respectively. The watercress grown in NDS at $\mathrm{d} 9$ had a higher AA content than that grown in DS $(+56 \%)$. The AA content was below the detection limit at both $\mathrm{d} 7$ and $\mathrm{d} 11$. The DHAA content was higher in DS than in NDS at d1, d7 and d11 (ca. $+24 \%)$, and NDS had a higher AA content than DS at d5 (+18\%). NBI had a higher DHAA content than $\mathrm{BI}$ at both $\mathrm{d} 1$ and $\mathrm{d} 5(+8 \%$ and $+23 \%$, respectively), which contrasted what occurred at $\mathrm{d} 7$ and $\mathrm{d} 11$ when BI had a higher DHAA content than NBI $(+16 \%$ and $+63 \%$, respectively).

In this study, the AA-to-DHAA ratio remained constantly in favour of DHAA during the entire shelf-life period. The general reduction in vitamin $C$ registered for fresh-cut watercress could have been due to the absence of light in the display cabinet, as light is one of the factors responsible for new AA synthesis [73].

Regarding the mineral nutrient content, the $\mathrm{PO}_{4}{ }^{3-}$ content was higher in $\mathrm{BI}$ than in $\mathrm{NBI}$ at $\mathrm{d} 1(+10 \%)$. The disinfection $\times$ B. subtilis interaction showed an increased value for the $\mathrm{PO}_{4}{ }^{3-}$ content at $\mathrm{d} 3, \mathrm{~d} 9$ and $\mathrm{d} 11$; both of the main factors influenced the $\mathrm{PO}_{4}{ }^{3-}$ content over time, with the exception of the B. subtilis inoculation at $\mathrm{d} 5$ (Table 9). DS $\times$ BI showed the highest $\mathrm{PO}_{4}{ }^{3-}$ content at $\mathrm{d} 3$ and $\mathrm{d} 11$ and the lowest content at $\mathrm{d} 7$ and $\mathrm{d} 9 . \mathrm{NDS} \times \mathrm{BI}$ had the lowest $\mathrm{PO}_{4}{ }^{3-}$ content at $\mathrm{d} 3$ and the highest content at $\mathrm{d} 9$. NDS $\times \mathrm{NBI}$ had the highest $\mathrm{PO}_{4}{ }^{3-}$ content at d7. DS $\times$ NBI had the lowest value at d11. DS had a higher $\mathrm{PO}_{4}{ }^{3-}$ content than NDS at both $\mathrm{d} 1$ and $\mathrm{d} 5$ (ca. $+16 \%$ ). 
Table 9. Phosphate $\left(\mathrm{PO}_{4}{ }^{3-}\right)$ and calcium carbonate $\left(\mathrm{CaCO}_{3}\right)$ contents in the fresh-cut watercress during its shelf life (NDS: non-disinfected substrate; DS: disinfected substrate; NBI: non-inoculated seeds and substrates; BI: seeds and substrates inoculated with B. subtilis). The results are expressed per fresh weight $(\mathrm{FW})$.

\begin{tabular}{|c|c|c|c|c|c|c|c|c|c|c|c|c|c|}
\hline & \multicolumn{6}{|c|}{$\mathrm{PO}_{4}{ }^{3-}\left(\mathrm{mg} \mathrm{g}^{-1} \mathrm{FW}\right)$} & \multicolumn{7}{|c|}{$\mathrm{CaCO}_{3}\left(\mathrm{mg} \mathrm{g}^{-1} \mathrm{FW}\right)$} \\
\hline & d1 & d3 & d5 & d7 & d9 & d11 & d1 & d3 & d5 & & d7 & d9 & d11 \\
\hline \multicolumn{14}{|l|}{ Disinfection } \\
\hline NDS & $0.120 b^{z}$ & $0.125 \mathrm{~b}$ & $0.117 \mathrm{~b}$ & $0.150 \mathrm{a}$ & $0.148 \mathrm{a}$ & $0.128 \mathrm{~b}$ & $0.033 \mathrm{a}$ & 0.027 & 0.036 & a & $0.034 \mathrm{a}$ & $0.034 \quad \mathrm{a}$ & $0.030 \mathrm{a}$ \\
\hline DS & 0.134 a & $0.144 \mathrm{a}$ & 0.142 a & $0.132 \mathrm{~b}$ & $0.140 \mathrm{~b}$ & $0.135 \mathrm{a}$ & $0.026 \mathrm{~b}$ & 0.027 & 0.024 & $\mathrm{~b}$ & $0.026 \mathrm{~b}$ & $0.024 \quad b$ & $0.021 \mathrm{~b}$ \\
\hline \multicolumn{14}{|l|}{ B. subtilis } \\
\hline NBI & $0.121 \mathrm{~b}$ & $0.130 \mathrm{~b}$ & 0.129 & $0.147 \mathrm{a}$ & $0.140 \mathrm{~b}$ & $0.125 \mathrm{~b}$ & $0.031 \mathrm{a}$ & $0.030 \mathrm{a}$ & 0.028 & $\mathrm{~b}$ & 0.030 & 0.029 & $0.024 \mathrm{~b}$ \\
\hline $\mathrm{BI}$ & 0.133 a & $0.138 \mathrm{a}$ & 0.130 & $0.135 \mathrm{~b}$ & $0.147 \mathrm{a}$ & $0.137 \mathrm{a}$ & $0.029 \mathrm{~b}$ & $0.024 \mathrm{~b}$ & 0.032 & a & 0.029 & 0.029 & $0.027 \mathrm{a}$ \\
\hline \multicolumn{14}{|l|}{ Disinfection $\times$ B. subtilis } \\
\hline NDS $\times$ NBI & 0.113 & 0.130 & 0.118 & 0.152 & 0.139 & 0.126 & 0.035 & 0.033 & 0.033 & & 0.035 & 0.035 & 0.028 \\
\hline $\mathrm{NDS} \times \mathrm{BI}$ & 0.128 & 0.119 & 0.117 & 0.149 & 0.156 & 0.130 & 0.032 & 0.021 & 0.038 & & 0.032 & 0.032 & 0.033 \\
\hline $\mathrm{DS} \times \mathrm{NBI}$ & 0.129 & 0.130 & 0.141 & 0.142 & 0.141 & 0.125 & 0.027 & 0.027 & 0.024 & & 0.026 & 0.024 & 0.020 \\
\hline $\mathrm{DS} \times \mathrm{BI}$ & 0.139 & 0.158 & 0.143 & 0.122 & 0.138 & 0.144 & 0.025 & 0.027 & 0.025 & & 0.026 & 0.025 & 0.022 \\
\hline Mean & 0.127 & 0.134 & 0.129 & 0.141 & 0.144 & 0.131 & 0.030 & 0.027 & 0.030 & & 0.030 & 0.029 & 0.026 \\
\hline SE & 0.003 & 0.003 & 0.002 & 0.004 & 0.002 & 0.002 & 0.001 & 0.001 & $<0.001$ & & 0.001 & $<0.001$ & 0.001 \\
\hline \multicolumn{14}{|l|}{ Significance } \\
\hline Disinfection & $<0.001$ & $<0.001$ & $<0.001$ & $<0.001$ & 0.001 & 0.005 & $<0.001$ & 0.884 & $<0.001$ & & $<0.001$ & $<0.001$ & $<0.001$ \\
\hline B. subtilis & $<0.001$ & 0.001 & 0.815 & 0.002 & 0.003 & $<0.001$ & 0.012 & $<0.001$ & $<0.001$ & & 0.184 & 0.208 & $<0.001$ \\
\hline Disinfection $\times$ B. subtilis & 0.502 & $<0.001$ & 0.482 & 0.016 & $<0.001$ & 0.002 & 0.505 & $<0.001$ & 0.002 & & 0.084 & $<0.001$ & 0.167 \\
\hline
\end{tabular}

${ }^{\mathrm{z}}$ Values in the same column following the same letter are not statistically different at $p<0.05$ according to F-test. Disinfection $\times B$. subtilis values are the means of the replicates. SE: standard error.

The substrate disinfection increased the $\mathrm{CaCO}_{3}$ content over time, apart from at $\mathrm{d} 3$; the $B$. subtilis inoculation increased the $\mathrm{CaCO}_{3}$ content from d1 to d5 and at d11 (Table 9). The disinfection $\times$ B. subtilis interaction decreased the $\mathrm{CaCO}_{3}$ content at $\mathrm{d} 3$, $\mathrm{d} 5$ and $\mathrm{d} 9$; NDS $\times$ NBI had the highest $\mathrm{CaCO}_{3}$ content at $\mathrm{d} 3$ and $\mathrm{d} 9 ; \mathrm{NDS} \times \mathrm{BI}$ had the lowest $\mathrm{CaCO}_{3}$ content at $\mathrm{d} 3$ and the highest at $\mathrm{d} 5$; and $\mathrm{DS} \times \mathrm{NBI}$ had the lowest $\mathrm{CaCO}_{3}$ content at both $\mathrm{d} 5$ and $d 9$. NDS resulted in a higher $\mathrm{CaCO}_{3}$ content than DS at $\mathrm{d} 1, \mathrm{~d} 7$ and $\mathrm{d} 11$ (ca. $+35 \%$ ). NBI showed a higher $\mathrm{CaCO}_{3}$ content at $\mathrm{d} 1$ than $\mathrm{BI}(+8 \%)$, which had a higher $\mathrm{CaCO}_{3}$ content than NBI at d11 (+15\%).

Nitrate content is an important quality characteristic, and the EU encourages good agricultural practices to reduce the nitrate contents in leafy vegetables [74]. In this study, the substrate disinfection decreased the $\mathrm{NO}_{3}{ }^{-}$content over time; the B. subtilis inoculation affected the $\mathrm{NO}_{3}{ }^{-}$content at $\mathrm{d} 1$ and from $\mathrm{d} 5$ to $\mathrm{d} 9$ (Table 10). The interaction between disinfection $\times$ B. subtilis evidenced a reduction in $\mathrm{NO}_{3}{ }^{-}$content at $\mathrm{d} 1, \mathrm{~d} 3, \mathrm{~d} 9$ and $\mathrm{d} 11$; $\mathrm{NDS} \times \mathrm{NBI}$ had the highest $\mathrm{NO}_{3}{ }^{-}$content at $\mathrm{d} 1$, and the lowest content was found in $\mathrm{DS} \times \mathrm{BI}$, not only at $\mathrm{d} 1$ but also at $\mathrm{d} 3$ and $\mathrm{d} 11$. NDS $\times \mathrm{BI}$ showed the highest $\mathrm{NO}_{3}{ }^{-}$ content at $\mathrm{d} 3, \mathrm{~d} 9$ and $\mathrm{d} 11$. The lowest $\mathrm{NO}_{3}{ }^{-}$content at $\mathrm{d} 9$ was found in DS $\times \mathrm{NBI}$. NDS and NBI had a higher $\mathrm{NO}_{3}{ }^{-}$content than DS and $\mathrm{BI}$ at both $\mathrm{d} 5$ and $\mathrm{d} 7$ (ca. $+81 \%$ and ca. $+12 \%$, respectively). In general, the ion content in fresh-cut watercress was stable or slowly decreased during the shelf life, as also reported in other studies $[75,76]$ in which the authors demonstrated that that the nitrate content remained constant in different types of green lettuce during storage. Specifically, Konstantopoulou and co-authors [76] found that the nitrate level in lettuce decreased at storage temperatures of 5 and $10{ }^{\circ} \mathrm{C}$ for 10 days. Siomos et al. [77] reported that the nitrate content found in romaine lettuce remained unchanged during storage at $1{ }^{\circ} \mathrm{C}$ from 3 to 15 days. Similar results were obtained in a study in which the authors indicated that the nitrate content of spinach was unchanged during storage at $5^{\circ} \mathrm{C}$ for 7 days but was reduced at higher temperatures [78]. 
Table 10. Nitrate $\left(\mathrm{NO}_{3}{ }^{-}\right)$content in the fresh-cut watercress during its shelf life (NDS: non-disinfected substrate; DS: disinfected substrate; NBI: non-inoculated seeds and substrates; BI: seeds and substrates inoculated with B. subtilis). The results are expressed per fresh weight (FW).

\begin{tabular}{|c|c|c|c|c|c|c|c|c|c|c|c|c|}
\hline & \multicolumn{12}{|c|}{$\mathrm{NO}_{3}^{-}\left(\mathrm{mg} \mathrm{g}^{-1} \mathrm{FW}\right)$} \\
\hline & \multicolumn{2}{|c|}{ d1 } & \multicolumn{2}{|c|}{ d3 } & \multicolumn{2}{|c|}{ d5 } & \multicolumn{2}{|c|}{ d7 } & \multicolumn{2}{|c|}{ d9 } & \multicolumn{2}{|c|}{ d11 } \\
\hline \multicolumn{13}{|l|}{ Disinfection } \\
\hline NDS & 2.80 & $a^{z}$ & 2.17 & $\mathrm{a}$ & 1.96 & a & 2.11 & $\mathrm{a}$ & 2.27 & $\mathrm{a}$ & 2.14 & a \\
\hline DS & 1.62 & $\mathrm{~b}$ & 1.43 & $\mathrm{~b}$ & 1.09 & $\mathrm{~b}$ & 1.16 & $\mathrm{~b}$ & 1.39 & $\mathrm{~b}$ & 1.16 & $\mathrm{~b}$ \\
\hline \multicolumn{13}{|l|}{ B. subtilis } \\
\hline NBI & 2.31 & $\mathrm{a}$ & 1.87 & & 1.64 & a & 1.69 & $\mathrm{a}$ & 1.75 & $b$ & 1.66 & \\
\hline BI & 2.10 & $\mathrm{~b}$ & 1.73 & & 1.41 & $b$ & 1.58 & $b$ & 1.91 & $\mathrm{a}$ & 1.64 & \\
\hline \multicolumn{13}{|l|}{ Disinfection $\times$ B. subtilis } \\
\hline NDS $\times$ NBI & 2.95 & & 2.11 & & 2.08 & & 2.17 & & 2.13 & & 2.05 & \\
\hline NDS × BI & 2.64 & & 2.23 & & 1.84 & & 2.05 & & 2.41 & & 2.24 & \\
\hline $\mathrm{DS} \times \mathrm{NBI}$ & 1.67 & & 1.63 & & 1.21 & & 1.21 & & 1.37 & & 1.27 & \\
\hline $\mathrm{DS} \times \mathrm{BI}$ & 1.57 & & 1.23 & & 0.97 & & 1.11 & & 1.41 & & 1.05 & \\
\hline Mean & 2.21 & & 1.80 & & 1.53 & & 1.64 & & 1.83 & & 1.65 & \\
\hline SE & 0.03 & & 0.07 & & 0.04 & & 0.03 & & 0.03 & & 0.04 & \\
\hline \multicolumn{13}{|l|}{ Significance } \\
\hline Disinfection & $<0.001$ & & $<0.001$ & & $<0.001$ & & $<0.001$ & & $<0.001$ & & $<0.001$ & \\
\hline B. subtilis & $<0.001$ & & 0.055 & & $<0.001$ & & $<0.001$ & & $<0.001$ & & 0.649 & \\
\hline Disinfection $\times$ B. subtilis & 0.001 & & 0.001 & & 0.930 & & 0.639 & & $<0.001$ & & $<0.001$ & \\
\hline
\end{tabular}

${ }^{\mathrm{z}}$ Values in the same column following the same letter are not statistically different at $p<0.05$ according to F-test. Disinfection $\times B$. subtilis values are the means of the replicates. SE: standard error.

\section{Conclusions}

Watercress is a rarely studied BLV that is suitable for processing as a fresh-cut product. During shelf life in this study, the watercress respiration rate followed the expected $\mathrm{O}_{2}$ consumption and $\mathrm{CO}_{2}$ production trends in the fresh-cut salad bag headspace, with the former only being below $2 \%$ at $\mathrm{d} 11$. The inherent phytochemical compounds were mostly retained in fresh-cut salad bags prepared with watercress grown in a disinfected substrate throughout the shelf-life period but less clearly in the seeds and substrates inoculated with PGPR. The external quality, during the shelf life, was slightly affected by a pigment content decrease and a browning enzyme activity increase. These metabolic reactions occurred at different intensities according to the different watercress growing conditions. The effect of Bacillus subtilis during the postharvest period was not fully exploited due to inconsistency in its performance during our study. The results evidenced the complex and cumulative effects of Bacillus subtilis due to the interactions between plants, microorganism, and environmental factors. The mechanisms adopted by these rhizobacteria in the postharvest physiology of plants remain to be fully explored. Indeed, different plant species or cultivars can produce different types of root exudates that support the activity of the inoculated microorganisms and also serve as substrates for the formation of biologically active substances by the microorganisms. The inoculated microorganisms must survive in the selected formulation and produce the desired activity following inoculation in the field. Additional research is thus needed to gain a better understanding of the fate of the phytochemical content in fresh-cut watercress treated with PGPR during the shelf-life period, particularly in function of the raw material quality.

Author Contributions: Conceptualization, D.N., J.A.F., C.E.-G. and S.N.; methodology, S.N. and G.P.; software, M.C.; validation, G.P. and M.C.; formal analysis, G.P. and M.C.; investigation, D.N., G.P. and M.C.; resources, S.N., J.A.F. and C.E.-G.; data curation, G.P. and M.C.; writing-original draft preparation, G.P., M.C. and S.N.; writing-review and editing, A.E., S.N., J.A.F. and C.E-G.; visualization, A.E.; supervision, S.N.; project administration, S.N. and J.A.F.; funding acquisition, S.N. and J.A.F. All authors have read and agreed to the published version of the manuscript.

Funding: The present work has partially been financed by the VEGMAP-DISAFA, the University of Turin, Project Ref. n. NICS1INT10, partially by the Spanish project MICINN-FEDER AGL2010-17680 and partially by the Spanish Seneca Foundation, Ref. n. 1887/IV/13. 
Institutional Review Board Statement: Not applicable.

Informed Consent Statement: Not applicable.

Data Availability Statement: All data included in the main text.

Conflicts of Interest: The authors declare no conflict of interest.

\section{References}

1. Palaniswamy, U.R.; McAvoy, R.J. Watercress: A salad crop with chemopreventive potential. Horttechnology 2001, 11, 622-626. [CrossRef]

2. Engelen-Eigles, G.; Holden, G.; Cohen, J.D.; Gardner, G. The effect of temperature, photoperiod, and light quality on gluconasturtiin concentration in watercress (Nasturtium officinale R. Br.). J. Agric. Food Chem. 2006, 54, 328-334. [CrossRef]

3. Cruz, R.M.S.; Vieira, M.C.; Silva, C.L.M. Effect of cold chain temperature abuses on the quality of frozen watercress (Nasturtium officinale R. Br.). J. Food Eng. 2009, 94, 90-97. [CrossRef]

4. Pignata, G.; Niñirola, D.; Casale, M.; Lo Turco, P.E.; Egea-Gilabert, C.; Fernández, J.A.; Nicola, S. Inherent quality and safety of watercress grown in a floating system using Bacillus subtilis. Hortic. J. 2016, 85, 148-153. [CrossRef]

5. Voutsina, N.; Payne, A.C.; Hancock, R.D.; Clarkson, G.J.J.; Rothwell, S.D.; Chapman, M.A.; Taylor, G. Characterization of the watercress (Nasturtium officinale R. Br.; Brassicaceae) transcriptome using RNASeq and identification of candidate genes for important phytonutrient traits linked to human health. BMC Genomics 2016, 17, 1-16. [CrossRef]

6. Nicola, S.; Fontana, E. Fresh-Cut Produce Quality: Implications for a Systems Approach. In Postharvest Handling: A Systems Approach; Florkowski, W.J., Banks, N., Shewfelt, R.L., Prussia, S.E., Eds.; Academic Press: Cambridge, MA, USA, $2014 ;$ pp. $217-273$. ISBN 978-0-12-408137-6.

7. López-Ayerra, B.; Antonia Murcia, M.; Garcia-Carmona, F. Lipid peroxidation and chlorophyll levels in spinach during refrigerated storage and after industrial processing. Food Chem. 1998, 61, 113-118. [CrossRef]

8. Conte, A.; Conversa, G.; Scrocco, C.; Brescia, I.; Laverse, J.; Elia, A.; Del Nobile, M.A. Influence of growing periods on the quality of baby spinach leaves at harvest and during storage as minimally processed produce. Postharvest Biol. Technol. 2008, 50, 190-196. [CrossRef]

9. Noichinda, S.; Bodhipadma, K.; Mahamontri, C.; Narongruk, T.; Ketsa, S. Light during storage prevents loss of ascorbic acid, and increases glucose and fructose levels in Chinese kale (Brassica oleracea var. alboglabra). Postharvest Biol. Technol. 2007, 44, 312-315. [CrossRef]

10. Moon, K.M.; Kwon, E.B.; Lee, B.; Kim, C.Y. Recent Trends in Controlling the Enzymatic Browning of Fruit and Vegetable Products Molecules 2020, 25, 2754. [CrossRef] [PubMed]

11. Iakimova, E.T.; Woltering, E.J. Nitric oxide prevents wound-induced browning and delays senescence through inhibition of hydrogen peroxide accumulation in fresh-cut lettuce. Innov. Food Sci. Emerg. Technol. 2015, 30, 157-169. [CrossRef]

12. Degl'Innocenti, E.; Pardossi, A.; Tognoni, F.; Guidi, L. Physiological basis of sensitivity to enzymatic browning in 'lettuce', 'escarole' and 'rocket salad' when stored as fresh-cut products. Food Chem. 2007, 104, 209-215. [CrossRef]

13. Baur, S.; Klaiber, R.G.; Koblo, A.; Carle, R. Effect of different washing procedures on phenolic metabolism of shredded, packaged iceberg lettuce during storage. J. Agric. Food Chem. 2004, 52, 7017-7025. [CrossRef] [PubMed]

14. Llorach, R.; Martínez-Sánchez, A.; Tomás-Barberán, F.A.; Gil, M.I.; Ferreres, F. Characterisation of polyphenols and antioxidant properties of five lettuce varieties and escarole. Food Chem. 2008, 108, 1028-1038. [CrossRef] [PubMed]

15. Martínez-Sánchez, A.; Gil-Izquierdo, A.; Gil, M.I.; Ferreres, F. A comparative study of flavonoid compounds, vitamin C, and antioxidant properties of baby leaf Brassicaceae species. J. Agric. Food Chem. 2008, 56, 2330-2340. [CrossRef]

16. Clarkson, G.J.J.; O’Byrne, E.E.; Rothwell, S.D.; Taylor, G. Identifying traits to improve postharvest processability in baby leaf salad. Postharvest Biol. Technol. 2003, 30, 287-298. [CrossRef]

17. Scuderi, D.; Restuccia, C.; Chisari, M.; Barbagallo, R.N.; Caggia, C.; Giuffrida, F. Salinity of nutrient solution influences the shelf-life of fresh-cut lettuce grown in floating system. Postharvest Biol. Technol. 2011, 59, 132-137. [CrossRef]

18. Selma, M.V.; Luna, M.C.; Martínez-Sánchez, A.; Tudela, J.A.; Beltrán, D.; Baixauli, C.; Gil, M.I. Sensory quality, bioactive constituents and microbiological quality of green and red fresh-cut lettuces (Lactuca sativa L.) are influenced by soil and soilless agricultural production systems. Postharvest Biol. Technol. 2012, 63, 16-24. [CrossRef]

19. Leon, A.P.; Frezza, D.; Logegaray, V.R.; Mastrototaro, C.; Chiesa, A. Watercress (Nasturtium officinale R. BR.) minimally pro-cessed: Effect of storage temperature and different films of packaging. J. Ornam. Plants 2012, 2, 265-270.

20. Colelli, G.; Elia, A. I prodotti ortofrutticoli di IV gamma: Aspetti fisiologici e tecnologici. Italus Hortus 2009, 16, 55-78.

21. Randazzo, C.L.; Scifò, G.O.; Tomaselli, F.; Caggia, C. Polyphasic characterization of bacterial community in fresh cut salads. Int. J. Food Microbiol. 2009, 128, 484-490. [CrossRef]

22. Martínez-Sánchez, A.; Luna, M.C.; Selma, M.V.; Tudela, J.A.; Abad, J.; Gil, M.I. Baby-leaf and multi-leaf of green and red lettuces are suitable raw materials for the fresh-cut industry. Postharvest Biol. Technol. 2012, 63, 1-10. [CrossRef]

23. Rodríguez-Hidalgo, S.; Artés-Hernández, F.; Gómez, P.A.; Ferńandez, J.A.; Artés, F. Quality of fresh-cut baby spinach grown under a floating trays system as affected by nitrogen fertilisation and innovative packaging treatments. J. Sci. Food Agric. 2010, 90, 1089-1097. [CrossRef] [PubMed] 
24. Nicola, S.; Pignata, G.; Ferrante, A.; Bulgari, R.; Cocetta, G.; Ertani, A. Water Use Efficiency in Greenhouse Systems and Its Application in Horticulture. AgroLife Sci. J. 2020, 9, 248-262.

25. Nicola, S.; Egea-Gilabert, C.; Niñirola, D.; Conesa, E.; Pignata, G.; Fontana, E.; Fernández, J.A. Nitrogen and aeration levels of the nutrient solution in soilless cultivation systems as important growing conditions affecting inherent quality of baby leaf vegetables: A review. Acta Hortic. 2015, 1099, 167-178. [CrossRef]

26. Fontana, E.; Nicola, S. Producing garden cress (Lepidium sativum L.) for the fresh-cut chain using a soilless culture system. J. Hortic. Sci. Biotechnol. 2008, 83, 23-32. [CrossRef]

27. Oleńska, E.; Małek, W.; Wójcik, M.; Swiecicka, I.; Thijs, S.; Vangronsveld, J. Beneficial features of plant growth-promoting rhizobacteria for improving plant growth and health in challenging conditions: A methodical review. Sci. Total Environ. 2020, 743, 140682. [CrossRef]

28. Bharti, N.; Pandey, S.S.; Barnawal, D.; Patel, V.K.; Kalra, A. Plant growth promoting rhizobacteria Dietzia natronolimnaea modulates the expression of stress responsive genes providing protection of wheat from salinity stress. Sci. Rep. 2016, 6, 34768. [CrossRef]

29. Almaghrabi, O.A.; Massoud, S.I.; Abdelmoneim, T.S. Influence of inoculation with plant growth promoting rhizobacteria (PGPR) on tomato plant growth and nematode reproduction under greenhouse conditions. Saudi J. Biol. Sci. 2013, 20, 57-61. [CrossRef]

30. Liu, S.; Yang, B.; Liang, Y.; Xiao, Y.; Fang, J. Prospect of phytoremediation combined with other approaches for remediation of heavy metal-polluted soils. Environ. Sci. Pollut. Res. 2020, 27, 16069-16085. [CrossRef]

31. Pereira, F. Rhizobacteria as Bioprotectants Against Stress Conditions BT-Plant Growth Promoting Rhizobacteria for Sustainable Stress Management: Volume 1: Rhizobacteria in Abiotic Stress Management; Sayyed, R.Z., Arora, N.K., Reddy, M.S., Eds.; Springer: Singapore, 2019; pp. 157-177. ISBN 978-981-13-6536-2.

32. ALKahtani, M.D.F.; Attia, K.A.; Hafez, Y.M.; Khan, N.; Eid, A.M.; Ali, M.A.M.; Abdelaal, K.A.A. Chlorophyll fluorescence parameters and antioxidant defense system can display salt tolerance of salt acclimated sweet pepper plants treated with chitosan and plant growth promoting rhizobacteria. Agronomy 2020, 10, 1180. [CrossRef]

33. Sarhan, H. Effect of Bio and Mineral Fertilization on Yield and Quality of Sugar Beet. J. Plant Prod. 2012, 3, 2513-2524. [CrossRef]

34. Khan, N.; Bano, A.M.D.; Babar, A. Impacts of plant growth promoters and plant growth regulators on rainfed agriculture. PLoS ONE 2020, 15, e0231426. [CrossRef] [PubMed]

35. Hashem, A.; Tabassum, B.; Fathi Abd_Allah, E. Bacillus subtilis: A plant-growth promoting rhizobacterium that also impacts biotic stress. Saudi J. Biol. Sci. 2019, 26, 1291-1297. [CrossRef] [PubMed]

36. Dukare, A.S.; Paul, S.; Nambi, V.E.; Gupta, R.K.; Singh, R.; Sharma, K.; Vishwakarma, R.K. Exploitation of microbial antagonists for the control of postharvest diseases of fruits: A review. Crit. Rev. Food Sci. Nutr. 2019, 59, 1498-1513. [CrossRef]

37. El Ghaouth, A.; Wilson, C.; Wisniewski, M. Biologically-Based Alternatives to Synthetic Fungicides for the Control of Postharvest diseases of Fruit and Vegetables BT-Diseases of Fruits and Vegetables: Volume II: Diagnosis and Management; Naqvi, S.A.M.H., Ed.; Springer: Dordrecht, The Netherlands, 2004; pp. 511-535. ISBN 978-1-4020-2607-2.

38. Sharma, R.R.; Singh, D.; Singh, R. Biological control of postharvest diseases of fruits and vegetables by microbial antagonists: A review. Biol. Control 2009, 50, 205-221. [CrossRef]

39. Recep, K.; Fikrettin, S.; Erkol, D.; Cafer, E. Biological control of the potato dry rot caused by Fusarium species using PGPR strains. Biol. Control 2009, 50, 194-198. [CrossRef]

40. Niñirola, D.; Fernández, J.A.; Conesa, E.; Martínez, J.A.; Egea-Gilabert, C. Combined effects of growth cycle and different levels of aeration in nutrient solution on productivity, quality, and shelf life of watercress (Nasturtium officinale R. Br.) plants. HortScience 2014, 49, 567-573. [CrossRef]

41. Nicola, S.; Pignata, G.; Casale, M.; Lo Turco, P.E.; Gaino, W. Overview of a lab-scale pilot plant for studying baby leaf vegetables grown in soilless culture. Hortic. J. 2016, 85, 97-104. [CrossRef]

42. Zhan, L.J.; Fontana, E.; Tibaldi, G.; Nicola, S. Qualitative and physiological response of minimally processed garden cress (Lepidium sativum L.) to harvest handling and storage conditions. J. Food Agric. Environ. 2009, 7, 43-50.

43. Benzie, I.F.F.; Strain, J.J. The ferric reducing ability of plasma (FRAP) as a measure of 'antioxidant power': The FRAP assay. Anal. Biochem. 1996, 239, 70-76. [CrossRef]

44. Singleton, V.L.; Rossi, J.A. Colorimetry of Total Phenolics with Phosphomolybdic-Phosphotungstic Acid Reagents. Am. J. Enol. Vitic. 1965, 16, 144-158.

45. Couture, R.; Cantwell, M.I.; Ke, D.; Saltveit, M.E. Physiological Attributes Related to Quality Attributes and Storage Life of Minimally Processed Lettuce. HortScience 1993, 28, 723-725. [CrossRef]

46. Tardelli, F.; Guidi, L.; Massai, R.; Toivonen, P.M. Effects of 1-methylcyclopropene and post-controlled atmosphere air storage treatments on fresh-cut Ambrosia apple slices. J. Sci. Food Agric. 2013, 93, 262-270. [CrossRef] [PubMed]

47. Degl'Innocenti, E.; Guidi, L.; Pardossi, A.; Tognoni, F. Biochemical study of leaf browning in minimally processed leaves of lettuce (Lactuca sativa L. var. acephala). J. Agric. Food Chem. 2005, 53, 9980-9984. [CrossRef]

48. Campos, R.; Nonogaki, H.; Suslow, T.; Saltveit, M.E. Isolation and characterization of a wound inducible phenylalanine ammonialyase gene (LsPAL1) from Romaine lettuce leaves. Physiol. Plant. 2004, 121, 429-438. [CrossRef]

49. Todeschini, V.; Aitlahmidi, N.; Mazzucco, E.; Marsano, F.; Gosetti, F.; Robotti, E.; Bona, E.; Massa, N.; Bonneau, L.; Marengo, E.; et al. Impact of beneficial microorganisms on strawberry growth, fruit production, nutritional quality, and volatilome. Front. Plant Sci. 2018, 9, 1-22. [CrossRef] 
50. Mena-Violante, H.G.; Cruz-Hernández, A.; Paredes-Lóopez, O.; Gomez-Lim, M.Á.; Olalde-Portugal, V. Fruit texture related changes and enhanced shelf-life through tomato root inoculation with Bacillus subtilis BEB-13BS. Agrociencia $2009,43,559-567$.

51. Kim, J.G.; Luo, Y.; Gross, K.C. Effect of package film on the quality of fresh-cut salad savoy. Postharvest Biol. Technol. 2004, 32, 99-107. [CrossRef]

52. Martínez-Sánchez, A.; Allende, A.; Bennett, R.N.; Ferreres, F.; Gil, M.I. Microbial, nutritional and sensory quality of rocket leaves as affected by different sanitizers. Postharvest Biol. Technol. 2006, 42, 86-97. [CrossRef]

53. Arvanitoyannis, I.S.; Bouletis, A.D.; Papa, E.A.; Gkagtzis, D.C.; Hadjichristodoulou, C.; Papaloucas, C. Microbial and sensory quality of ' Lollo verde' lettuce and rocket salad stored under active atmosphere packaging. Anaerobe 2011, 17, 307-309. [CrossRef] [PubMed]

54. Nicola, S.; Hoeberechts, J.; Fontana, E. Rocket (Eruca sativa Mill.) and corn salad (Valerianella olitoria L.): Production and shelf-life of two leafy vegetables grown in a soilless culture system. Acta Hortic. 2004, 633, 509-516. [CrossRef]

55. Ertani, A.; Nardi, S.; Francioso, O.; Pizzeghello, D.; Tinti, A.; Schiavon, M. Metabolite targeted analysis and physiological traits of zea mays L. In response to application of a leonardite-humate and lignosulfonate-based products for their evaluation as potential biostimulants. Agronomy 2019, 9, 445. [CrossRef]

56. Kałużewicz, A.; Baczek-Kwinta, R.; Krzesiński, W.; Spiżewski, T.; Zaworska, A. Effect of biostimulants on chlorophyll fluorescence parameters of broccoli (Brassica oleracea var. Italica) under drought stress and rewatering. Acta Sci. Pol. Hortorum Cultus 2018, 17, 97-106. [CrossRef]

57. Ertani, A.; Sambo, P.; Nicoletto, C.; Santagata, S.; Schiavon, M.; Nardi, S. The use of organic biostimulants in hot pepper plants to help low input sustainable agriculture. Chem. Biol. Technol. Agric. 2015, 2. [CrossRef]

58. Fallovo, C.; Rouphael, Y.; Rea, E.; Battistelli, A.; Colla, G. Nutrient solution concentration and growing season affect yield and quality of Lactuca sativa L. var. acephala in floating raft culture. J. Sci. Food Agric. 2009, 89, 1682-1689. [CrossRef]

59. Nicola, S.; Fontana, E.; Tibaldi, G.; Zhan, L. Qualitative and physiological response of minimally processed rocket (Eruca sativa Mill.) to package filling amount and shelf-life temperature. Acta Hortic. 2010, 877, 611-618. [CrossRef]

60. Gonçalves, E.M.; Cruz, R.M.S.; Abreu, M.; Brandão, T.R.S.; Silva, C.L.M. Biochemical and colour changes of watercress (Nasturtium officinale R. Br.) during freezing and frozen storage. J. Food Eng. 2009, 93, 32-39. [CrossRef]

61. Cazzonelli, C.I.; Pogson, B.J. Source to sink: Regulation of carotenoid biosynthesis in plants. Trends Plant Sci. 2010, 15, 266-274. [CrossRef]

62. Santos, J.; Mendiola, J.A.; Oliveira, M.B.P.P.; Ibáñez, E.; Herrero, M. Sequential determination of fat- and water-soluble vitamins in green leafy vegetables during storage. J. Chromatogr. A 2012, 1261, 179-188. [CrossRef]

63. Aires, A.; Carvalho, R.; Rosa, E.A.S.; Saavedra, M.J. Phytochemical characterization and antioxidant properties of baby-leaf watercress produced under organic production system. CYTA-J. Food 2013, 11, 343-351. [CrossRef]

64. Backer, R.; Rokem, J.S.; Ilangumaran, G.; Lamont, J.; Praslickova, D.; Ricci, E.; Subramanian, S.; Smith, D.L. Plant growthpromoting rhizobacteria: Context, mechanisms of action, and roadmap to commercialization of biostimulants for sustainable agriculture. Front. Plant Sci. 2018, 871, 1-17. [CrossRef]

65. Zhan, L.; Li, Y.; Hu, J.; Pang, L.; Fan, H. Browning inhibition and quality preservation of fresh-cut romaine lettuce exposed to high intensity light. Innov. Food Sci. Emerg. Technol. 2012, 14, 70-76. [CrossRef]

66. Giannakourou, M.C.; Tsironi, T.N. Application of Processing and Packaging Hurdles for Fresh-Cut Fruits and Vegetables Preservation. Foods 2021, 10, 830. [CrossRef]

67. Watada, A.E.; Qi, L. Quality of fresh-cut produce. Postharvest Biol. Technol. 1999, 15, 201-205. [CrossRef]

68. Blokhina, O.; Virolainen, E.; Fagerstedt, K.V. Antioxidants, oxidative damage and oxygen deprivation stress: A review. Ann. Bot. 2003, 91, 179-194. [CrossRef] [PubMed]

69. Ertani, A.; Schiavon, M.; Muscolo, A.; Nardi, S. Alfalfa plant-derived biostimulant stimulate short-term growth of salt stressed Zea mays L. plants. Plant Soil 2013, 364, 145-158. [CrossRef]

70. Ertani, A.; Pizzeghello, D.; Francioso, O.; Tinti, A.; Nardi, S. Biological activity of vegetal extracts containing phenols on plant metabolism. Molecules 2016, 21, 205. [CrossRef]

71. Mhlongo, M.I.; Piater, L.A.; Steenkamp, P.A.; Labuschagne, N.; Dubery, I.A. Metabolic profiling of PGPR-treated tomato plants reveal priming-related adaptations of secondary metabolites and aromatic amino acids. Metabolites 2020, 10, 210. [CrossRef]

72. Popova, A. The effect of heating on the vitamin C content of selected vegetables. World J. Adv. Res. Rev. 2019, 3, 2581-9615 [CrossRef]

73. Zhan, L.; Hu, J.; Ai, Z.; Pang, L.; Li, Y.; Zhu, M. Light exposure during storage preserving soluble sugar and l-ascorbic acid content of minimally processed romaine lettuce (Lactuca sativa L.var. longifolia). Food Chem. 2013, 136, 273-278. [CrossRef] [PubMed]

74. Giménez, A.; Fernández, J.A.; Pascual, J.A.; Ros, M.; Saez-Tovar, J.; Martinez-Sabater, E.; Gruda, N.S.; Egea-Gilabert, C. Promising composts as growing media for the production of baby leaf lettuce in a floating system. Agronomy 2020, 10, 1540. [CrossRef]

75. Miceli, A.; Vetrano, F.; Sabatino, L.; D’Anna, F.; Moncada, A. Influence of preharvest gibberellic acid treatments on postharvest quality of minimally processed leaf lettuce and rocket. Horticulturae 2019, 5, 63. [CrossRef]

76. Konstantopoulou, E.; Kapotis, G.; Salachas, G.; Petropoulos, S.A.; Karapanos, I.C.; Passam, H.C. Nutritional quality of greenhouse lettuce at harvest and after storage in relation to $\mathrm{N}$ application and cultivation season. Sci. Hortic. 2010, 125, 93.e1-93.e5. [CrossRef] 
77. Siomos, A.S.; Papadopoulou, P.P.; Dogras, C.C.; Niklis, N.D. Quality of Romaine and leaf lettuce at harvest and during storage. Acta Hortic. 2002, 579, 641-646. [CrossRef]

78. Chung, J.-C.; Chou, S.-S.; Hwang, D.-F. Changes in nitrate and nitrite content of four vegetables during storage at refrigerated and ambient temperatures. Food Addit. Contam. 2004, 21, 317-322. [CrossRef] 